\title{
New records of Philopterus (Ischnocera: Philopteridae) from Acrocephalidae and Locustellidae, with description of one new species from Regulidae
}

\author{
Tomas NAJER ${ }^{1, *}$, Ivo PAPOUSEK ${ }^{2}$, Costica ADAM $^{3}$, Alfred TRNKA ${ }^{4}$, Van Thi QUACH ${ }^{5}$, \\ Chinh Ngoc NGUYEN ${ }^{6}$, Roman FIGURA ${ }^{7}$, Ivan LITERAK $^{8} \&$ Oldrich SYCHRA $^{9}$ \\ ${ }^{1}$ Department of Veterinary Sciences, Faculty of Agrobiology, Food and Natural Resources, \\ Czech University of Life Sciences, Kamycka 129, 16500 Prague 6, Czechia. \\ 2,5,8,9 Department of Biology and Wildlife Diseases, Faculty of Veterinary Hygiene and Ecology,
} University of Veterinary and Pharmaceutical Sciences, Palackeho tr. 1946/1, 61242 Brno, Czechia.

3 "Grigore Antipa" National Museum of Natural History,

Sos. Kiseleff no. 1, 011341 Bucharest 1, Romania.

${ }^{4}$ Department of Biology, University of Trnava, Priemyselna 4, 91843 Trnava, Slovakia.

${ }^{6}$ Department of Parasitology, Institute of Ecology and Biological Resources (IEBR), Vietnam Academy of Science and Technology (VAST), 18-Hoang Quoc Viet, Hanoi, Vietnam.

${ }^{7}$ Department of Philosophy and History of Science, Faculty of Science, Charles University, Vinicna 7, 12843 Prague 2, Czechia.

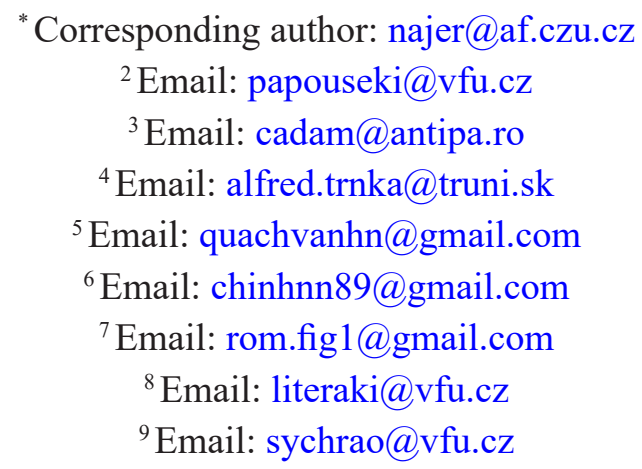

\footnotetext{
${ }^{1}$ urn:1sid:zoobank.org:author:08A25BDD-8CCD-4709-9A57-7CE235D473C7

${ }^{2}$ urn:Isid:zoobank.org:author:B30F1C9C-8AEF-41F8-8F0C-434189ACABE6

${ }^{3}$ urn:lsid:zoobank.org:author:1DDA0DD3-6617-40EE-8DD4-A215162E95F8

${ }^{4}$ urn:lsid:zoobank.org:author:67B34829-2A6A-48A8-9CB8-4AE98062E5B8

${ }^{5}$ urn:1sid:zoobank.org:author:57E2C9B3-8C06-4177-B89B-8CA31A3B8677

${ }^{6}$ urn:1sid:zoobank.org:author:E30B8CA5-4998-4016-9D4D-C4BB26E90640

${ }^{7}$ urn:lsid:zoobank.org:author:30A91AD9-F663-42FA-BE10-C41448136257

${ }^{8}$ urn:lsid:zoobank.org:author:1 A328AC3-67A8-4F79-86DB-81E3DB0661C8

${ }^{9}$ urn:1sid:zoobank.org:author:D28CEAFB-0F34-4937-A66E-6AC8BA90E325
} 


\begin{abstract}
One species of the louse genus Philopterus Nitzsch, 1818 is redescribed and illustrated: Philopterus acrocephalus Carriker, 1949 ex Acrocephalus luscinius (Quoy \& Gaimard, 1830), A. melanopogon (Temminck, 1823), A. scirpaceus (Hermann, 1804), A. schoenobaenus (Linnaeus, 1758), Iduna aedon rufescens Stegmann, 1929, I. rama (Sykes, 1832), Locustella sp. and L. ochotensis (von Middendorff, 1853). Philopterus acrocephalus represents the first species of the Philopteruscomplex recorded in the family Locustellidae Bonaparte, 1854. Philopterus gustafssoni sp. nov. is described ex Regulus regulus (Linnaeus, 1758), $R$. regulus regulus (Linnaeus, 1758), $R$. regulus azoricus Seebohm, 1883, $R$. regulus buturlini von Loudon, 1911, $R$. regulus sanctaemariae Vaurie, 1954, $R$. regulus tristis Pleske, 1892 and $R$. ignicapillus (Temminck, 1820). Descriptions of both species are amended with genetic data, DNA sequences of mitochondrial cytochrome oxidase I, nuclear hyp and TMEDE6; concatenated sequences are compared to the morphologically nearest species with genetic data available, Philopterus citrinellae (Schrank, 1776) and Philopterus fringillae (Scopoli, 1772). Holotype of Philopterus reguli (Denny, 1842) is pronounced to be a straggler, determination of other known material from Regulidae is changed for Philopterus gustafssoni sp. nov.
\end{abstract}

Keywords. Chewing lice, Passeriformes, reed warblers, kinglets.

Najer T., Papousek I., Adam C., Trnka A., Quach V.T., Nguyen C.N., Figura R., Literak I. \& Sychra O. 2020. New records of Philopterus (Ischnocera: Philopteridae) from Acrocephalidae and Locustellidae, with description of one new species from Regulidae. European Journal of Taxonomy 632: 1-37. https://doi.org/10.5852/ejt.2020.632

\title{
Introduction
}

In the past, the taxonomy of chewing lice passed through several periods during which different species definitions were applied. One of them was the approach that the lice in each host-louse association constitute separate species, regardless of morphological similarity to species known from other host species. This approach was applied assuming automatically that the lice are so host-specific that an eventual host switching is practically impossible. Nowadays we know that lice actually can switch hosts (e.g., Sychra et al. 2014a) and also that the phylogenies of lice do not always match with those of their hosts (Johnson et al. 2002). However, from time to time we are still obliged to come to terms with the inheritance of this period. This is also the case with the Philopterus-complex (obvious in Fedorenko 1987; Złotorzycka 1964), of which no thorough taxonomic revision was made since that time.

Within the Philopterus-complex, one of the groups concerned are Philopterus Nitzsch, 1818 species occurring in reed-warblers (Acrocephalidae Salvin, 1882) and kinglets (Regulidae Vigors, 1825). To date, four records of Philopterus species from the family Acrocephalidae have been published (Table 1) and practically no description of the any of them can be considered as complete. They are either based on a single sex only (Carriker 1949; Złotorzycka 1964) or their relevance may be disputable as the presented diagnostic features are, in our view, tentative and not sufficient to separate new species (Mey 1983). Therefore, we are confident to provide here a more detailed redescription of Ph. acrocephalus Carriker, 1949, based on examination of both museum specimens (including the female holotype) and our freshly collected material. In addition, we also provide the first record of this species in the family Locustellidae Bonaparte, 1854. The other Philopterus species described from Acrocephalidae are probably synonyms of $P h$. acrocephalus, but we do not suggest the synonymization here because the type material for comparison is lacking.

Concerning kinglets (Regulidae), the only species known from this host family is Philopterus reguli (Denny, 1842), so far recorded only in goldcrest, Regulus regulus regulus (Linnaeus, 1758). After examination of the holotype deposited in the Natural History Museum, London, United Kingdom (NHML), we noticed that this specimen is different from any other Philopterus material known from 
Table 1. To date described species of Philopterus complex from the family Acrocephalidae.

\begin{tabular}{lll}
\hline Species & Type host & Type locality \\
\hline Philopterus acrocephalus & $\begin{array}{l}\text { Acrocephalus luscinius } \\
\text { (Quoy \& Gaimard, 1830) }\end{array}$ & Guam \\
$\begin{array}{l}\text { Carriker, 1949 } \\
\text { (Złopterus mirificus }\end{array}$ & $\begin{array}{l}\text { Acrocephalus palustris } \\
\text { (Bechstein, 1798) }\end{array}$ & Poland \\
$\begin{array}{l}\text { Philopterus necopinatus } \\
\text { (Złotorzycka, 1964) }\end{array}$ & $\begin{array}{l}\text { Acrocephalus schoenobaenus } \\
\text { (Linnaeus, 1758) }\end{array}$ & Poland \\
$\begin{array}{l}\text { Philopterus fedorenkoae } \\
\text { (Mey, 1983) }\end{array}$ & $\begin{array}{l}\text { Acrocephalus arundinaceus } \\
\text { arundiceus (Linnaeus, 1758) }\end{array}$ & Turkmenistan \\
\hline
\end{tabular}

this family. Therefore, we consider the holotype to be a straggler and Ph. reguli to be an invalid name. We here describe the other by us examined material as a new species, Philopterus gustafssoni sp. nov. Because our work chronologically follows those of Złotorzycka \& Lucińska (1976) which put Philopterus from both Acrocephalidae and Regulidae in one species group (see below), we hereby refer to both these groups together.

In our study, we managed to gather DNA sequences of one mitochondrial and two nuclear markers from both Ph. acrocephalus and Ph. gustafssoni sp. nov. Therefore, we supply the redescriptions with genetic data as well.

\section{Material and methods}

The type material of Philopterus acrocephalus is represented by a single female, which is furthermore rather aged with some morphological characteristics hardly visible. Therefore, the redescription of this species was based mainly on material collected from moustached warbler, Acrocephalus melanopogon (Temminck, 1823) in Gbelce (Slovakia), Letea (Romania) and Nea Agathoupoli (Greece). Examined birds originated from dense reed (Phragmites australis (Cav.) Trin. ex Steud.) growths where the moustached warbler is relatively common; in the case of Gbelce it is the only breeding site in Slovakia and the northernmost one in the species' range (Trnka \& Capek 2002).

To confirm the identity of Ph. acrocephalus, the holotype, from Acrocephalus luscinius (Quoy \& Gaimard, 1830), mounted on slides in Canada balsam and deposited in the National Museum of Natural History, Smithsonian Institution, Washington, D.C., USA (USNM), was used (Fig. 1). For further comparison and confirmation of new host-louse associations, museum material from Acrocephalus melanopogon, Acrocephalus schoenobaenus (Linnaeus, 1758) and Iduna aedon Stegmann, 1929, mounted on slides in Canada balsam and deposited in the Zoological Institute, Russian Academy of Sciences, St. Petersburg, Russia (ZIN), was used. In addition, we also examined one specimen of Philopterus sp. from A. schoenobaenus mounted on slide and deposited in the USNM, one specimen from I. aedon, mounted on slide and deposited in the ZIN and three nymphs from Acrocephalus palustris (Bechstein, 1798) deposited in the collection of J. Złotorzycka in the Museum of Natural History, University of Wrocław, Wrocław, Poland (MNHW). All these lice could not be determined at the species level. The three nymphs are currently the only representatives of Philopterus from Acrocephalidae preserved in Złotorzycka's collection, the rest has to be considered as lost.

For the morphological part of the description of Ph. gustafssoni sp. nov. we used material collected from Regulus regulus regulus in coniferous forests at the various locations in the Czech Republic. Furthermore, some more specimens of Ph. gustafssoni sp. nov. were obtained in field work targeted mainly on Fringillidae Leach, 1820 in Moravske Kninice (Czechia). We also morphologically examined 
museum material from Złotorzycka's collection (MNHW). Since this material was stored inappropriately for DNA preservation, for the genetic analyses we used material collected on the Azores, Portugal. After DNA extraction, the vouchers were also mounted on slides and examined morphologically.

In order to collect material, birds were captured alive, examined, deloused as described in Sychra et al. (2009) and subsequently released. Identifications of birds were based on Svensson et al. (2009) but their taxonomy follows Clements et al. (2018). The mounted slides will be deposited in the Moravian Museum, Brno, Czechia (MMBC) and the "Grigore Antipa" National Museum of Natural History (MGAB), Bucharest, Romania. The examined museum material will be returned to the National Museum of Natural History, Smithsonian Institution, Washington, D.C., USA (USNM), the Zoological Institute, Russian Academy of Sciences, St. Petersburg, Russia (ZIN) and the Museum of Natural History, University of Wrocław, Wrocław, Poland (MNHW). For determination of identity of Philopterus reguli and description of Philopterus gustafssoni sp. nov., material deposited in the Natural History Museum, London, United Kingdom (NHML) was used. Additional material, which was not mounted on slides, is deposited in the personal collection of Oldrich Sychra at the University of Veterinary and Pharmaceutical Sciences, Brno, Czechia (UVPS).

The terminology, dimensions taken and chaetotaxy of head and body follow Najer et al. (2016). Leg chaetotaxy follows Gustafsson et al. (2019). To draw the figures, the following procedure was followed: drawings were made with (1) a CX21FS1 light wide-field upright microscope (Olympus, Tokyo, Japan) fitted with a drawing tube; after drawing, the illustrations were edited using Adobe Illustrator CS6 on a tablet PTZ-930 (Wacom, China); or (2) a Nikon Eclipse TI-E inverted light microscope (Nikon, Tokyo, Japan) fitted with an Andor Clara camera (Oxon, United Kingdom); background photos for the drawings were taken using NIS Elements 4.50.00 LO (Nikon, Tokyo, Japan); after drawing, the illustrations were edited using GIMP (available on https://www.gimp.org, downloaded in October 2018) on an Intuos 3 PTZ-1230 tablet (Wacom, China). All dimensions are given in millimeters and were taken using an optical scale in the light microscope, between the same points as explained in Najer et al. (2016) and shown in Figs 2-3. The nomenclature of setae presented by Gustafsson \& Bush (2017) for the Brueelia complex was partially applied here for setae that were not assessed in Najer et al. (2016). This concerns in particular the abdominal setae, with the difference that psps (postspiracular principal setae) and tps (tergal posterior setae) could not be distinguished in Philopterus from Acrocephalidae and Regulidae, so they are counted together and presented as $t c s$ (tergocentral setae) in this paper. Aps (accessory postspiracular setae) are missing in all the specimens examined, so they are not further mentioned. The abbreviations used for the other setae groups are shown in Fig. 3: $p s=$ paratergal seta; $s s=$ sutural seta; $s t s=$ sternal seta. In addition, the presence of the ats (= anterior tergal seta), introduced by Cicchino \& Castro (1996), is also assessed. In the head chaetotaxy the pts = posttemporal seta is added, which was not visible in material studied by Najer et al. (2016). The $m s=$ mental setae were not mentioned in any previous Philopterus-related literature but we observed them in all examined specimens, so we introduce the term here. The pos = postocular seta is named "preocular" by Gustafsson \& Bush (2017), however, it is placed behind the eye, not in front of it. Therefore we rename it here, keeping for it the same abbreviation. In the thoracic chaetotaxy, we introduce term pterothoracic lateral seta $(p t l s)$ for the group of setae placed in the lateral corner of pterothorax (Fig. 3).

For the genetic analyses, DNA was extracted using a commercial Quigen Blood and Tissue kit. The set of extracts was amplified with the polymerase chain reaction (PCR) using primers commonly used for amplification of the mitochondrial cytochrome oxidase I (COI, primers COI-L6625 and COI-H7005) gene and the primers presented by Sweet et al. (2014) for the nuclear loci hyp (BR50-181L and BR50621R) and TMEDE6 (BR69-190F and BR69-432R). These first PCRs were set up in $25 \mu 1$, using $3 \mu 1$ of DNA extract, and run at the INHS in PTC-100 Peltier Thermal Cycler (MJ Research, Waltham, MA) using the following protocol: denaturation at $94^{\circ} \mathrm{C}$ for 2 minutes, then cycles of denaturation at $94^{\circ} \mathrm{C}$ for 
$30 \mathrm{~s}$, annealing at $46^{\circ} \mathrm{C}$ for $30 \mathrm{~s}$, extension at $72^{\circ} \mathrm{C}$ for $30 \mathrm{~s}$, repeated 35 times and a final extension step at $72^{\circ} \mathrm{C}$ for 7 minutes. In a few samples, in which some marker did not amplify, the reaction was repeated in $50 \mu \mathrm{l}$ volume; if the reaction still did not proceed, the volume of DNA extract was increased from 3 to $5 \mu \mathrm{l}$ (and $\mathrm{dH}_{2} \mathrm{O}$ reduced to $16 \mu \mathrm{l}$ ). After PCR, the samples were purified with Gel/PCR DNA Fragments Extraction Kit (Geneaid, Taiwan) according to the standard protocol and subsequently sequenced by the commercial service of Macrogen, Amsterdam, The Netherlands. The obtained respective sequences of the COI, hyp and TMEDE6 genes were aligned in Geneious 9.1.8 (Kearse et al. 2012). In order to assess genetic divergence of the obtained sequences and other taxa examined by us, net average interspecific $p$-distances between $P h$. acrocephalus, Ph. gustafssoni sp. nov. and their two probably nearest relatives (Najer, unpublished results) - Philopterus citrinellae (Schrank, 1776) and Philopterus fringillae (Scopoli, 1772) - were computed in MEGA 7.0.14 (Kumar et al. 2016) using four datasets: COI (379 bp), hyp (386 bp), TMEDE6 (220 bp), and the concatenated sequences of all three fragments (985 bp).

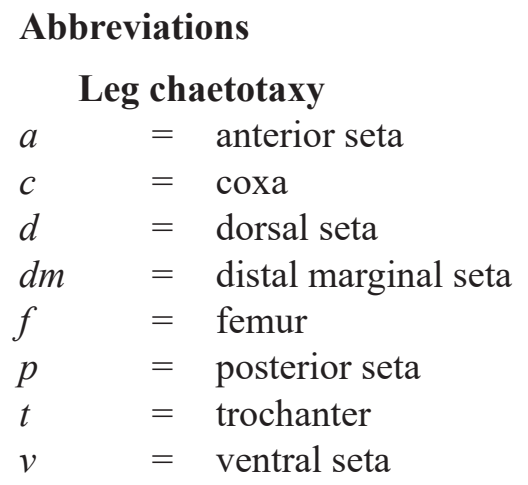

\section{Sclerites}

\begin{tabular}{|c|c|c|}
\hline $\operatorname{sgp}$ & $=$ & subgenital plate \\
\hline svs & $=$ & subvulvar sclerite \\
\hline vs VII & $=$ & vestigial sternite VIII \\
\hline \multicolumn{3}{|c|}{ Setae } \\
\hline$a d s$ & $=$ & anterior dorsal seta \\
\hline as & $=$ & anterior seta \\
\hline ats & $=$ & anterior tergal seta \\
\hline avs & $=$ & anterior ventral seta \\
\hline dsms & $=$ & dorsal submarginal seta \\
\hline$m d s$ & $=$ & mandibular seta \\
\hline$m s$ & $=$ & mental seta \\
\hline$m t s$ & $=$ & marginal temporal seta \\
\hline os & $=$ & ocular seta \\
\hline pas & $=$ & preantennal seta \\
\hline$p c s$ & $=$ & preconal seta \\
\hline plts & $=$ & setae on lateral part of pterothorax \\
\hline pns & $=$ & postnodal seta \\
\hline pos & $=$ & postocular seta \\
\hline pps & $=$ & pronotal post-spiracular seta \\
\hline ps & $=$ & paratergal seta \\
\hline pths & $=$ & pterothoracic seta \\
\hline ptls & $=$ & pterothoracic lateral seta \\
\hline pts & $=$ & postemporal seta \\
\hline & $=$ & sensillus \\
\hline
\end{tabular}




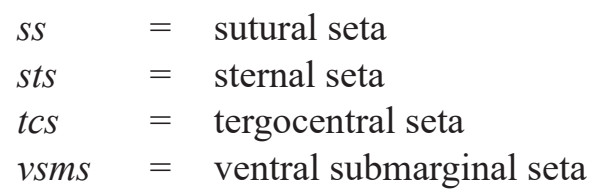

\section{Body parts}

$\mathrm{ADP}=$ dorsal anterior preantennal plate

$\mathrm{EM}=$ endomere

$\mathrm{MM}=$ mesomere

\section{Measurements}

$\mathrm{ADPL}=$ anterior dorsal plate length

$\mathrm{ADPW}=$ anterior dorsal plate width

$\mathrm{AL}=$ length of abdomen

ANW $=$ anterior notch width

APLL $=$ anterior dorsal plate lateral length

$\mathrm{AW}=$ maximal width of abdomen

EWG $=$ external width of genital chamber

$\mathrm{GL}=$ male genitalia length

$\mathrm{GW}=$ male genitalia width

$\mathrm{HL}=$ head length

IWG $=$ internal width of genital chamber

PAL $=$ preantennal length

$\mathrm{PAW}=$ preantennal width

PMCL $=$ premarginal carina length

POL $=$ postantennal length

PTL $=$ pterothorax length

PTW $=$ pterothorax width

$\mathrm{PW}=$ prothorax width

$\mathrm{TL}=$ total length

TPVL = tergal plate V length

$\mathrm{TRL}=$ trabecula length

TRW $=$ trabecula width

$\mathrm{TW}=$ temporal width

SGPW $=$ subgenital plate width

\section{Institutions acronyms}

MGAB $=$ "Grigore Antipa" National Museum of Natural History, Bucharest, Romania

$\mathrm{MMBC}=$ Moravian Museum, Brno, Czechia

MNHW $=$ Museum of Natural History, University of Wrocław, Wrocław, Poland

NHML $=$ Natural History Museum, London, United Kingdom

USNM $=$ National Museum of Natural History, Smithsonian Institution, Washington, D.C., USA

UVPS = personal collection of Oldrich Sychra at the University of Veterinary and Pharmaceutical Sciences, Brno, Czechia (UVPS)

ZIN = Zoological Institute, Russian Academy of Sciences, St. Petersburg, Russia

\section{Results}

All 28 examined A. melanopogon (11 in 2008, 9 in 2009 and 8 in 2016) caught at Gbelce were parasitized by $\mathrm{Ph}$. acrocephalus (100\% prevalence). Altogether 158 lice (44 males, 52 females and 62 nymphs) were collected at this location. At Nea Agathoupoli, only two of the 10 birds (prevalence 20\%) were 
parasitized and together three lice (one male, one female, one nymph) were gathered. Concerning Ph. gustafssoni sp. nov., 16 out of 54 examined $R$. regulus (30\%) and two of seven $R$. ignicapillus (Temminck, 1820) (29\%) were parasitised by this species (19 females, 15 males, 63 nymphs and 1 female and 4 nymphs were found, respectively).

Order Phthiraptera Haeckel, 1896

Suborder Ischnocera Kellogg, 1896

Family Philopteridae Burmeister, 1838

Philopterus complex (sensu Mey 2004)

Genus Philopterus Nitzsch, 1818

Type species: Philopterus ocellatus (Scopoli, 1764).

\section{Remarks}

Until now, all Philopterus known from both Acrocephalidae and Regulidae were included in so called "reguli" species group. This species group was established by Złotorzycka \& Lucińska (1976), but their description of the group is very general. It uses formulations which do not enable identification of this group without extensive comparison of large series of material (e.g., "mostly trapezoidal" or "mostly shaped differently than in another groups"). Besides Ph. reguli, the authors place in this group also Philopterus rubeculae (Denny, 1842), Philopterus capillatus (Złotorzycka, 1964), Philopterus desertus (Złotorzycka, 1964), Philopterus pallescens (Denny, 1842), Philopterus rutteri (Kellogg, 1899), Philopterus modularis (Denny, 1842), Philopterus emiliae Balat, 1955, Philopterus mirificus (Złotorzycka, 1964) and Philopterus necopinatus (Złotorzycka, 1964, the two latter species being known from Acrocephalus J.A. Naumann \& J.F. Naumann, 1811). In the end of the description they declare identity of the whole group as questionable.

Mey (1983) claims that diagnostic features of this group should be shape of head and anterior dorsal plate, pleural chaetotaxy of abdominal segment IV, chaetotaxy of pronotum and "characteristic features of male genitalia" (without being more concrete). However, in any of these characteristics he does not describe how should they look like to be diagnostic for the species group. He places to this group only Ph. reguli, Ph. pallescens and Ph. rutteri. For Ph. modularis and seven other species (Ph. emiliae, Ph. rubeculae, Ph. capillatus, Ph. desertus, Ph. davuricae Fedorenko \& Volkov, 1977, Ph. markevichi Fedorenko \& Volkov, 1977 and Ph. mugimaki Fedorenko \& Volkov, 1977), he newly established the modularis species group; however, he does not provide further description of this group. Concerning Philopterus fedorenkoae (Mey, 1983), Ph. mirificus and Ph. necopinatus, he states that their relationship to the reguli species group cannot be resolved until examination of more material.

We examined the holotype of Philopterus reguli (NHML). This specimen is morphologically different (e.g., in shape of head, shape of dorsal preantennal head plate, thoracic and abdominal chaetotaxy, shape of subgenital plate) from all other examined Philopterus from Regulidae. Therefore, we hereby pronounce it to be a straggler and below we describe the species infesting Regulidae as a new species, Philopterus gustafssoni sp. nov. We also examined the material on which Złotorzycka \& Lucińska (1976) based description of "reguli" species group. All these specimens (see below) are in fact Ph. gustafssoni sp. nov., so if the species group exists, it should be rather named gustafssoni species group. Concerning other species of the group, the types of Ph. mirificus and Ph. necopinatus are lost (Jaloszynski et al. 2014), so we could not assess morphological similarity of these two species and Ph. gustafssoni sp. nov. We tried to contact Eberhard Mey in order to get information about type material of Ph. fedorenkoae and specification of "reguli" (now gustafssoni) species group diagnosis, but without any success. Figures accompanying description of Ph. fedorenkoae (Mey 1983) show that this species differs from 
Ph. gustafssoni sp. nov. in several features (e.g., shape of head and dorsal head plate, pronotal chaetotaxy, shape of male subgenital plate), so it does not belong to the species group regardless it exists or not. We can also state that all by us examined Philopterus from Acrocephalus warblers (including those which might be Ph. fedorenkoae, see below) are clearly different from Ph. gustafssoni sp. nov. (see below) and do not form one species group. In other figures provided by Mey (1988), Ph. pallescens, Ph. rutteri, Philopterus hercynicus (Mey, 1988) and Philopterus peripariphilus (Mey, 1988) show similar head shape, anterior dorsal plate shape and pronotal chaetotaxy (with more than one pair of pronotal setae) as Ph. gustafssoni sp. nov. This paper, however, does not contain illustrations of male genitalia (except Ph. hercynicus) and subgenital plates. Therefore, we cannot resolve justification of this species group without extensive revision of Philopterus from Paridae Vigors, 1825. This revision is currently ongoing and it will be presented in a separate article, so hereby we only state that $P h$. acrocephalus does not belong to this species group.

Philopterus acrocephalus Carriker, 1949

Figs 1-5, 8A-B; Tables 2-5

\section{Material examined}

Holotype

USA • o (Fig. 1); Marianas, Guam Island; 4 Jun. 1945; R.H. Baker leg.; ex Acrocephalus luscinius luscinius; USNM No. 58960.

\section{Other material}

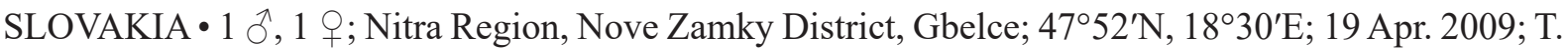
Najer \& O. Sychra leg.; ex Acrocephalus melanopogon; MMBC SK21 • 1 $\uparrow, 1$ q; same collection data as for preceding; MMBC SK22 $\bullet 1 \hat{\partial}, 1$ + ; same collection data as for preceding; MMBC SK23 1 o, 1 + ; same collection data as for preceding; MMBC SK24 • 1 ๙ (Fig. 8A), 1 q (Fig. 8B); same collection data as for preceding; MMBC SK25.

ROMANIA • 1 क ; Tulcea County, Letea; $45^{\circ} 20^{\prime} \mathrm{N}, 2^{\circ} 32^{\prime} \mathrm{E}$; 9 Apr. 2011; C. Adam leg.; same host as for preceding; MGAB ISC $317 \bullet 1$ \&; same collection data as for preceding; MGAB ISC $318 \bullet 1$ \&; same collection data as for preceding; MGAB ISC $319 \bullet 1$ त; same collection data as for preceding; MGAB

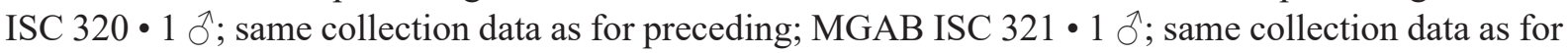
preceding; MGAB ISC 322.

AZERBAIJAN • $3 \hat{\jmath} \widehat{\partial}, 2$ 우; 18 Apr. 1937; A. Ivanov leg.; same host as for preceding; ZIN ・ 1 ठ, 4 우; 24 Apr. 1937; same collector and host as for preceding; ZIN.

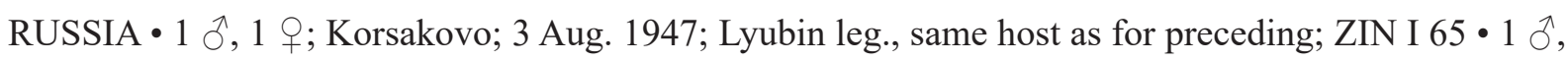
1 O; Astrakhan Oblast, Astrakhan State Nature Reserve; 9 Aug. 1946; ex Acrocephalus schoenobaenus; ZIN I-8 • 1 क; same collection data as for preceding; 14 Aug. 1946; ZIN I 12/7 • 1 đ̂; Amur Oblast, Tambovka on Amur District; 26 Jul. 1939; D.I. Blagoveshtchensky leg.; ex Iduna aedon rufescens; ZIN

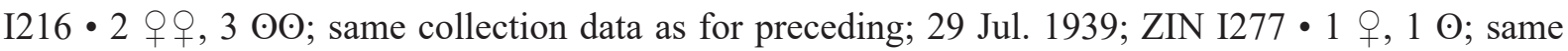
collection data as for preceding; 3 Aug. 1939; ZIN I341.

AUSTRIA • 1 subad. P; Burgenland, Neusiedl am See; 18 Sep. 1960; F. Balat leg.; ex Acrocephalus melanopogon; MMBC No. 1229.

TAJIKISTAN • 4 q ; Khatlon Region, Qurgonteppa; 29 May 1932; ex Iduna rama; ZIN I250/353 • 2 우; Districts of Republican Subordination, Gissar Range; 23 Apr. 1934; ex Locustella sp.; ZIN A-129. 
COUNTRY UNKNOWN・1 ふ̋’; 8 May 1909; A. Derzhavin leg.; ex Locustella ochotensis; ZIN.

\section{Additional collected material}

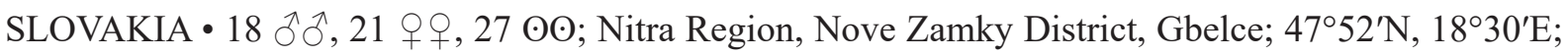
12 Apr.-3 May 2008; I. Literak, M. Capek \& O. Sychra leg.; ex Acrocephalus melanopogon; UVPS •

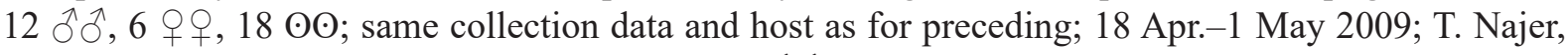

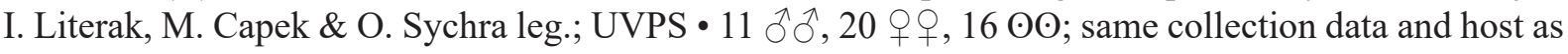
for preceding; 18-21 Apr. 2016; T. Najer, T. Judak, L. Oslejskova \& O. Sychra leg.; UVPS.

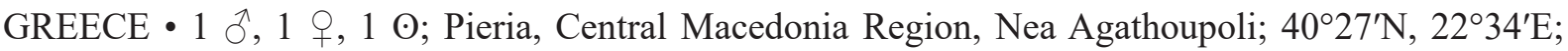
14 Dec. 2013; A. Diakou leg.; same host as for preceding; UVPS.

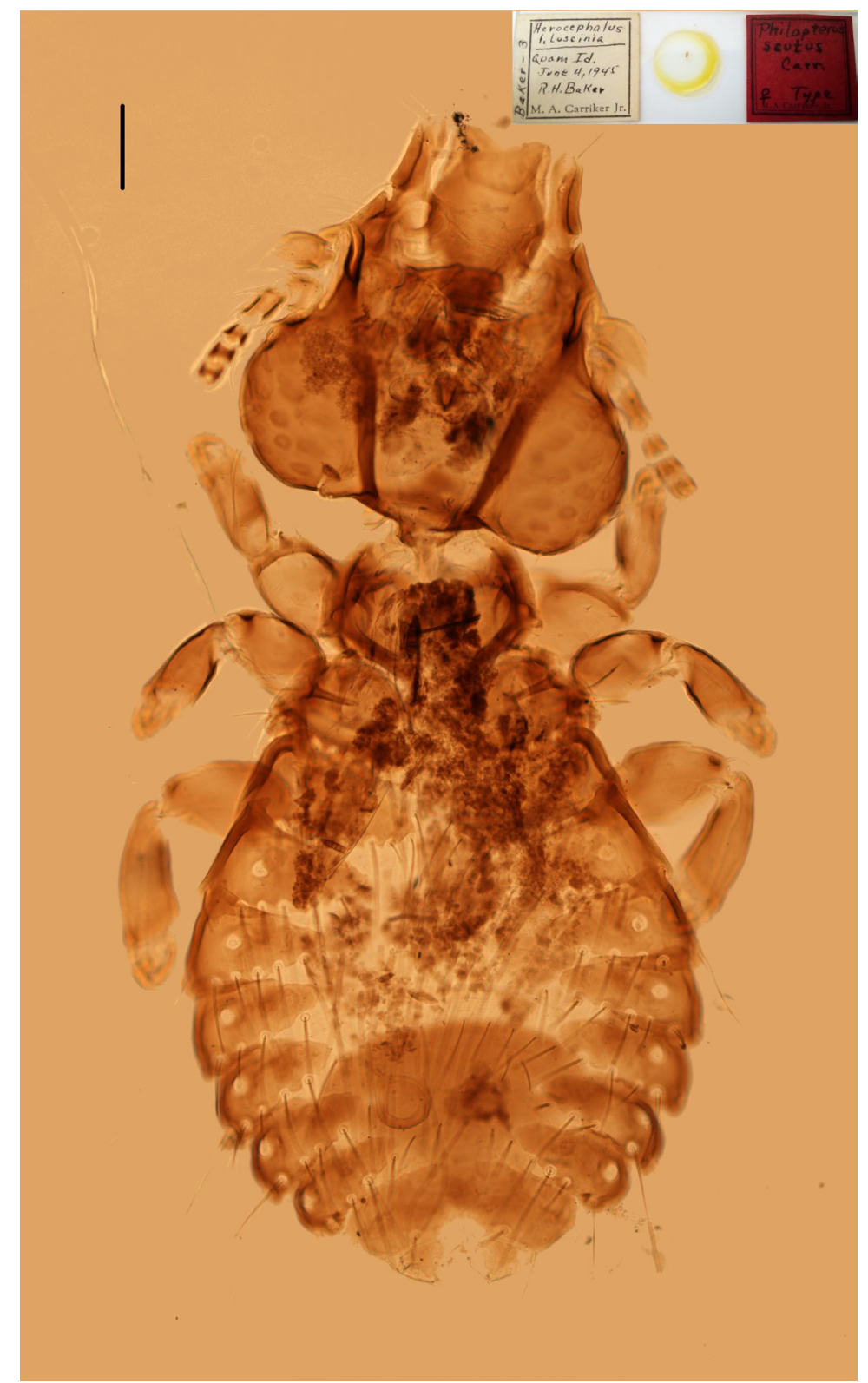

Fig. 1. Philopterus acrocephalus Carriker, 1949 ex Acrocephalus luscinius: female holotype (USNM No. 58960), dorsal view. Scale bar: $0.1 \mathrm{~mm}$. 


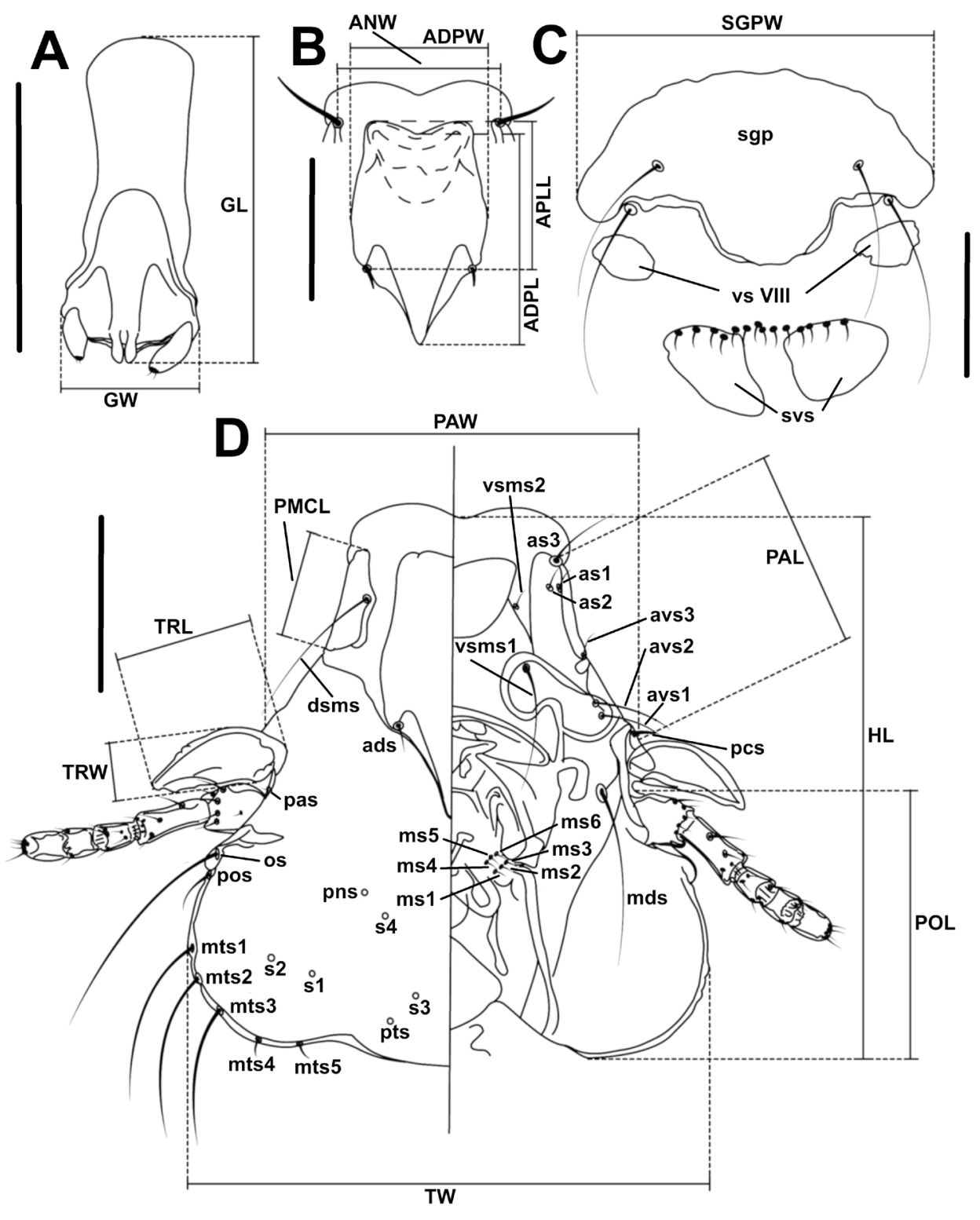

Fig. 2. Philopterus acrocephalus Carriker, 1949 ex Acrocephalus melanopogon (SK25 in MMBC): points of measurements and nomenclature of sclerites and setae. A. Male genitalia, ventral view. B. Male dorsal preantennal plate (ADP), dorsal view. C. Female subgenital plate and ventral terminalia, ventral view. D. Male head, dorsal and ventral views. Abbreviations: sclerites: $s g p$ - subgenital plate; $s v s$ - subvulvar sclerite; vs VIII - vestigial sternite VIII; setae: ads - anterior dorsal seta; as - anterior seta; avs - anterior ventral seta; $d s m s$ - dorsal submarginal seta; $m d s$ - mandibular seta; $m s$ - mental seta; $m t s$ - marginal temporal seta; os - ocular seta; pas - preantennal seta; pcs - preconal seta; pos postocular seta; pns - postnodal seta; $p t s$ - postemporal seta; $s$ - sensillus; vsms - ventral submarginal seta. Measurements: ADPL - anterior dorsal plate length; APLL - anterior dorsal plate lateral length; ADPW - anterior dorsal plate width; ANW - anterior notch width; GL - male genitalia length; GW male genitalia width; HL - head length; PAL - preantennal length; PAW - preantennal width; PMCL premarginal carina length; POL - postantennal length; TRL - trabecula length; TRW - trabecula width; TW - temporal width; SGPW - subgenital plate width. Scale bars: $0.1 \mathrm{~mm}$. 


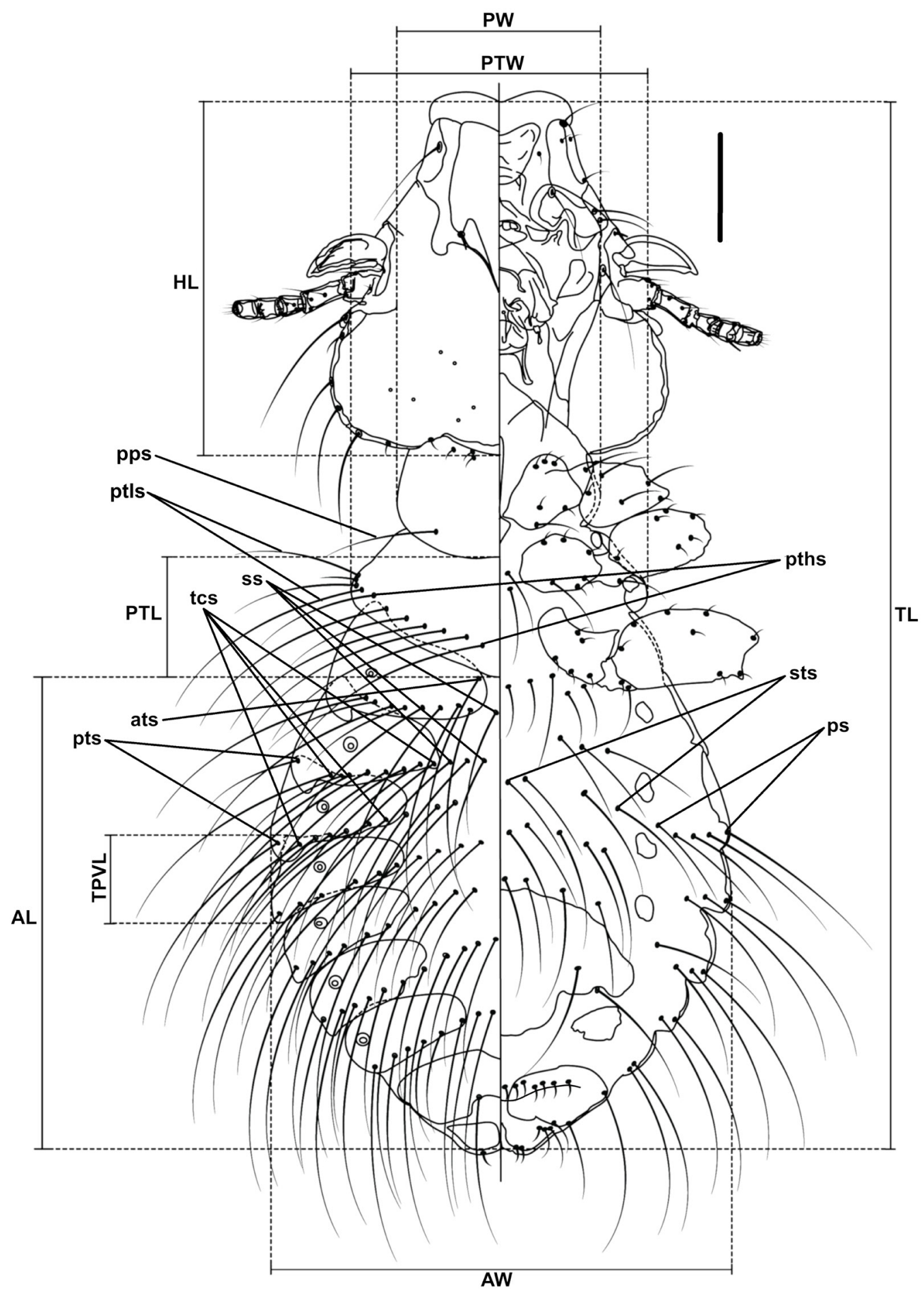

Fig. 3. Philopterus acrocephalus Carriker, 1949 ex Acrocephalus melanopogon (SK25 in MMBC): female habitus showing points of measurements and nomenclature of abdominal setae, dorsal and ventral views. Abbreviations: setae: ats - anterior tergal seta; $p s$ - paratergal seta; $p p s$ - pronotal postspiracular seta; $p t h s$ - pterothoracic seta; $p t l s$ - pterothoracic lateral seta; $s s$ - sutural seta; sts - sternal seta; $t c s$ - tergocentral seta. Measurements: AL - length of abdomen; AW - maximal width of abdomen; HL - head length; PTL - pterothorax length; PW - prothorax width; PTW - pterothorax width; TL total length; TPVL - tergal plate V length. Scale bars: $0.1 \mathrm{~mm}$. 


\section{Not determinable material}

In addition to the examined material of $P h$. acrocephalus, we examined the following specimens. They were noticeably different from $P h$. acrocephalus but could not be determined because of a lack of available material of other species for comparison.

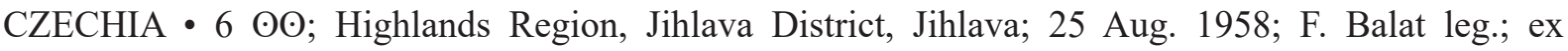
Acrocephalus scirpaceus; MMBC No. 1387.

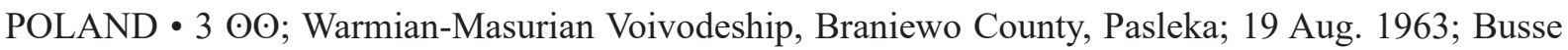
leg.; ex Acrocephalus palustris; labeled as Docophorulus mirificus; MNHW 8/i/4-6.

EGYPT • 1 \&; Bahiq; 7 Oct. 1966; ex Acrocephalus schoenobaenus; labeled as Philopterus necopinatus; USNM.

AUSTRIA • 1 subad. đ̊; Burgenland, Neusiedl am See; 17 Sep. 1960; F. Balat leg.; ex Acrocephalus scirpaceus; MMBC No. 1232.

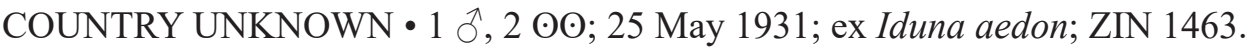

\section{Description}

\section{Both sexes}

Head as in Fig. 4C, slightly longer than wide, with frons slightly concave, preantennal region with slightly concave lateral margin approximately the same length as the postantennal margin. Hyaline margin enlarged, wider than frons. Dorsal anterior preantennal plate (ADP) as in Fig. 4B, with slightly centrally indented anterior margin and straight or slightly concave anterior part of lateral margin. Posterolateral margin of ADP straight or slightly concave, but not sclerotized and therefore almost not apparent, the sclerotization of ADP forming 1 wide, large central and 2 small lateral triangular projections with straight margin, the indentations between the central and lateral projections about the same size as the lateral projections, sharply angled (Fig. 4B). Ventral anterior plate as in Fig. 4C, with lateral and posterior margins continuously merging into 1 rounded postero-lateral margin. Prothorax as in Fig. 4A, E, with 1 long postero-lateral pps on each side and 3 short thorn-like setae on each side of its anterior margin. Prosternum narrow and elongated, mesosternum rhombic. In place of metasternum 2 medium-long setae on each side. Pterothorax with 5-6 long setae (pths) on each side. Pterothorax with lateral margins straight, reaching approximately to the same level as spiracles on segment II. Tergopleurites II-IX all with long most lateral seta, tergocentral setae $(t c s)$ generally very long, mostly overreaching length of 3 abdominal segments, sutural setae (ss) medium-long, about the length of 2 abdominal segments. Leg chaetotaxy as in Fig. 5, measurements as in Table 3.

\section{Male}

Habitus as in Fig. 4A, head as in Fig. 4C. Lateral parts of pterothorax with 4 separate setae (ptls) on each side, 1 medium-long $\left(1^{\text {st }}\right.$, counting from the most lateral $), 2$ short $\left(2^{\text {nd }}-3^{\text {rd }}\right)$ and 1 long $\left(4^{\text {th }}\right)$. Thoracic and abdominal chaetotaxy as in Fig. 4A and Table 2. Sternal setae (sts) on segments II-III short, on segments IV-VI medium long, shorter or approximately the same length as ss. Subgenital plate of rectangular shape, as in Fig. 4A, with rounded anterior margin, with only slight indentations on both lateral sides. Posterior margin of central part of subgenital plate not clear, 2 (median long and lateral medium-long) setae at the level of anterior lateral indentation and 1 medium-long seta at the level of posterior lateral indentation on each side. Genitalia as in Fig. 4D, basal apodeme long and quadrangular, lateral margins concave, anterior margin rounded. Parameres elongated, length about $1 / 2$ of width of basal plate, overreaching the mesosome, kidney-shaped, clearly separated from the basal plate, with 2 sensillae on each side of posterior margin. Mesosome consisting of 2 fingerlike parts, which are parallel 


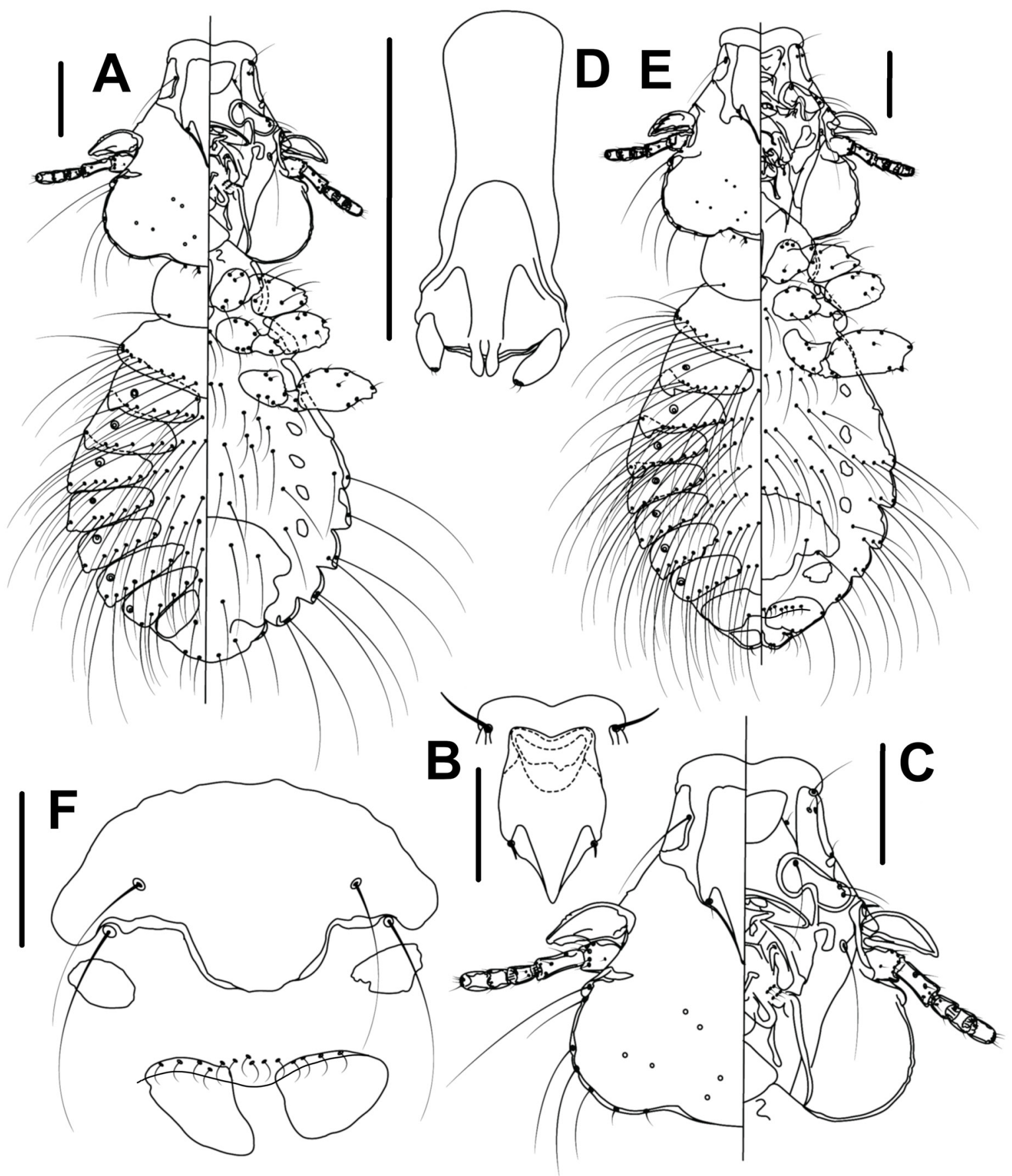

Fig. 4. Philopterus acrocephalus Carriker, 1949 ex Acrocephalus melanopogon (SK25 in MMBC). A. Male habitus, dorsal and ventral views. B. Male dorsal anterior plate (ADP), dorsal view. C. Male head, dorsal and ventral views. D. Male genitalia, ventral view. E. Female habitus, dorsal and ventral views. F. Female subgenital plate, vulval margin and ventral terminalia, ventral view. Scale bars: $0.1 \mathrm{~mm}$. 
to each other, proximally fused with basal plate, with bulbous distal part and bluntly pointed posteromedian end.

\section{Female}

Habitus as in Fig. 4E. Lateral part of pterothorax with 3 separate setae $(p t l s), 1^{\text {st }}$ and $3^{\text {rd }}$ counting from the most lateral medium-long, the $2^{\text {nd }}$ short. Thoracic and abdominal chaetotaxy as in Fig. 4E and Table 2. Sternal setae (sts) on segment II short, on the other segments medium-long, on segments III-IV shorter, on segments V-VI about the same length as ss, the most median VI sts longer than the others. Subgenital plate (Fig. 4F) with rounded anterior margin, concave posteriolateral margins and rounded central part of posterior margin. Posterio-lateral parts of subgenital plate separated as vestigial sternites VIII (Fig. 4F). Two long lateral setae on each side, 1 in area of original sternite VII, 1 behind the posterior margin of lateral sternite VII. Subvulval sclerites, associated chaetotaxy and vulval margin as in Fig. 4F. Inner genital sclerites missing, the area where the vulval margin is visible in other Philopterus species with a row of 7 short slender setae on each side.

\section{Hosts}

\section{Type host}

Acrocephalus luscinius (Quoy \& Gaimard, 1830).

\section{Other hosts}

Acrocephalus melanopogon (Temminck, 1823), Acrocephalus scirpaceus (Hermann, 1804), Acrocephalus schoenobaenus (Linnaeus, 1758) - from these three hosts, some Philopterus species are described, but it is not definitely confirmed that they are synonyms of Ph. acrocephalus. Therefore, we cannot exclude that material examined by us represents new host records. Iduna aedon rufescens Stegmann, 1929 - new host record, Iduna rama (Sykes, 1832) - new host record, Locustella sp. - new host record, Locustella ochotensis (von Middendorff, 1853) - new host record.

\section{Distribution}

Type locality

USA, Guam Island.

\section{Other published locations}

Czechia (Balat in Hudec 1983); Hungary (Vas et al. 2012a); Greece, Nea Agathoupoli (Diakou et al. 2017). Always mentioned as Philopterus sp. ex A. melanopogon, considered to be Ph. acrocephalus according to host association.

\section{Newly reported locations}

Slovakia, Gbelce; Romania, Letea; Greece, Nea Agathoupoli; Azebaijan without further specification; Russia, Astrakhan State Nature Reserve; Russia, Korsakov; Russia, Tambovka in Amur District; Tajikistan, Gissar Range; Tajikistan, Qurgonteppa; Austria, Neusiedl am See.

\section{Remarks}

Because the holotype is rather old and not all its morphological features are clearly visible, were used specimens of A. melanopogon collected in Slovakia for the drawings. The genitalia of the male used to draw all male figures differ in appearance from the other examined males due to the slide-mounting process. The mesosome of these male genitalia is bent upwards, so the shape is not clearly visible. For this reason, for the figure of the male genitalia, we used the mesosome of another specimen, the genitalia of which are otherwise the same as those of the mainly drawn specimen. Specimens of Ph. acrocephalus from Azerbaijan have a relatively more narrow central posterior projection of the ADP; in other ways, the morphological features are the same as in the other examined material. In general, the relative 
Table 2. Abdominal chaetotaxy for Philopterus acrocephalus Carriker, 1949 and Philopterus gustafssoni sp. nov. Numbers in parentheses are modes. Sternal code: 1 - long seta. Letters in parentheses under sternal code refer to missing setae in some specimens.

\begin{tabular}{lccccc}
\hline \multicolumn{5}{c}{ Abdominal chaetotaxy male Philopterus acrocephalus } \\
\hline Segment & Paratergal & Tergocentral & Sutural & Sternal number & Sternal code \\
\hline II & 0 & $5-8(6)$ & $0-1(1)$ & $2-5(3)$ & $111(11)-(11) 11$ \\
III & 1 & $5-8(7)$ & $0-4(3)$ & $3-6(3)$ & $111(1)-(111) 111$ \\
IV & $3-6(4)$ & $5-7(7)$ & $1-5(4)$ & $3-5(5)$ & $111(11)-(11) 111$ \\
V & $3-6(5)$ & $5-7(5)$ & $2-5(4)$ & $2-5(4)$ & $111(1)-(111) 11$ \\
VI & $3-5(3)$ & $4-7(6)$ & $2-6(4)$ & $2-5(4)$ & $11(111)-(111) 11$ \\
VII & $2-5(3)$ & $3-7(6)$ & $1-3(2)$ & & \\
VIII & $1-3(3)$ & $3-6(3)$ & $1-2(1)$ & \\
IX+X & \multicolumn{7}{c}{ Abdominal chaetotaxy female Philopterus acrocephalus } \\
\hline Segment & Paratergal & Tergocentral & Sutural & Sternal number & Sternal code \\
\hline II & 0 & $5-10(8)$ & $1-2(1)$ & $1-4(3)$ & $11(11)-(111) 1$ \\
III & 1 & $5-11(7)$ & $2-4(3)$ & $2-6(4)$ & $111(111)-(111) 11$ \\
IV & $2-7(5)$ & $3-12(6)$ & $2-6(4)$ & $2-7(3)$ & $11111)-(11111) 11$ \\
V & $4-7(5)$ & $3-11(5)$ & $2-5(4)$ & $3-6(4)$ & $11(111)-(111) 1$ \\
VI & $3-6(4)$ & $3-9(5)$ & $3-5(5)$ & $1-5(4)$ & \\
VII & $2-5(3)$ & $3-8(6)$ & $3-4(4)$ & & \\
VIII & $2-3(3)$ & $2-6(5)$ & $1-2(1)$ & & \\
IX+X & \multicolumn{7}{c}{ (5) } & $1-2(2)$ & &
\end{tabular}

Abdominal chaetotaxy male Philopterus gustafssoni sp. nov.

\begin{tabular}{lccccc}
\hline Segment & Paratergal & Tergocentral & Sutural & Sternal number & Sternal code \\
\hline II & 0 & $6-9(8)$ & $0-3(2)$ & $3-8(5)$ & $1111(111)-(11111) 111$ \\
III & $0-2(1)$ & $5-9(7)$ & $1-6(3)$ & $5-10(5)$ & $11111(11111)-(11111) 11111$ \\
IV & $1-9(3)$ & $5-10(7)$ & $2-8(7)$ & $5-10(9)$ & $11111(11111)-(11111) 11111$ \\
V & $2-8(5)$ & $4-9(7)$ & $4-9(6)$ & $5-12(8)$ & $11111111(1111)-(111111) 11111$ \\
VI & $2-8(4)$ & $6-8(6)$ & $5-8(7)$ & $5-10(8)$ & $11111(11111)-(111) 111111$ \\
VII & $0-6(4)$ & $4-7(7)$ & $4-6(5)$ & & \\
VIII & $1-6(2)$ & $2-5(3)$ & $0-2(0)$ & & \\
IX+X & & $0-1(1)$ & & & \\
\hline
\end{tabular}

Abdominal chaetotaxy female Philopterus gustafssoni sp. nov.

\begin{tabular}{lccccc}
\hline Segment & Paratergal & Tergocentral & Sutural & Sternal number & Sternal code \\
\hline II & 0 & $6-11(8)$ & $1-5(4)$ & $3-8(6)$ & $111(11111)-(1111) 111$ \\
III & $0-2(1)$ & $6-10(9)$ & $4-8(4)$ & $4-12(9)$ & $1111(111111)-(11111111) 1111$ \\
IV & $1-7(3)$ & $5-9(7)$ & $6-12(9)$ & $7-13(8)$ & $11111111(11111)-(111111) 1111111$ \\
V & $1-6(3)$ & $5-8(8)$ & $4-11(10)$ & $5-11(11)$ & $1111(111111)-(111111) 11111$ \\
VI & $1-8(4)$ & $5-9(6)$ & $5-11(9)$ & $4-12(8)$ & $11111(1111111)-(1111111) 1111$ \\
VII & $2-4(3)$ & $6-9(6)$ & $4-10(5)$ & & \\
VIII & $1-4(3)$ & $2-7(3)$ & $0-5(3)$ & & \\
IX+X & & $0-1(1)$ & & & \\
\hline
\end{tabular}


size of lateral and posterior ADP projections shows the largest variability of all the morphological characteristics.

\section{Genetic diversity}

Two specimens of Ph. acrocephalus from Acrocephalus melanopogon were genetically analysed, in which all three examined genes (mitochondrial COI, nuclear hyp and TMEDE6) amplified. Since both examined specimens were from the same host species, their sequences also showed $100 \%$ identity in all three genes and the concatenated sequences as well (Table 4). The three other species for genetic comparison, Ph. gustafssoni sp. nov. (net interspecific $p$-distances $23.1 \%$ for COI, $1.6 \%$ for hyp, $0.8 \%$ for TMEDE6 and $9.7 \%$ for the concatenated sequences), Ph. fringillae (24.5\% for COI, $1.8 \%$ for hyp, $1.4 \%$ for TMEDE 6 and $10.5 \%$ for the concatenated sequences) and $P$ h. citrinellae ( $19.8 \%$ for COI, $1.8 \%$ for hyp , $1.2 \%$ for TMEDE6 and $8.6 \%$ for the concatenated sequences) were chosen because their net interspecific $p$-distances from $P h$. acrocephalus were the shortest from all by us sequenced Philopterus samples (Najer, unpublished results). More details about these distances are given in Table 5.

\section{Philopterus fedorenkoae (Mey, 1983)}

\section{Material examined}

CZECHIA • 1 q; S Moravian Region, Breclav District, pond Nesyt; 22 May 1948; F. Balat leg.; ex Acrocephalus arundinaceus; MMBC No. $29 \bullet 4$ 웅, 1 ㅅ, 1 $\odot$; S Moravian Region, Breclav District, Lednice, Mlynsky pond; 8 May 1948; F. Balat leg.; same host as for preceding; labeled as Philopterus

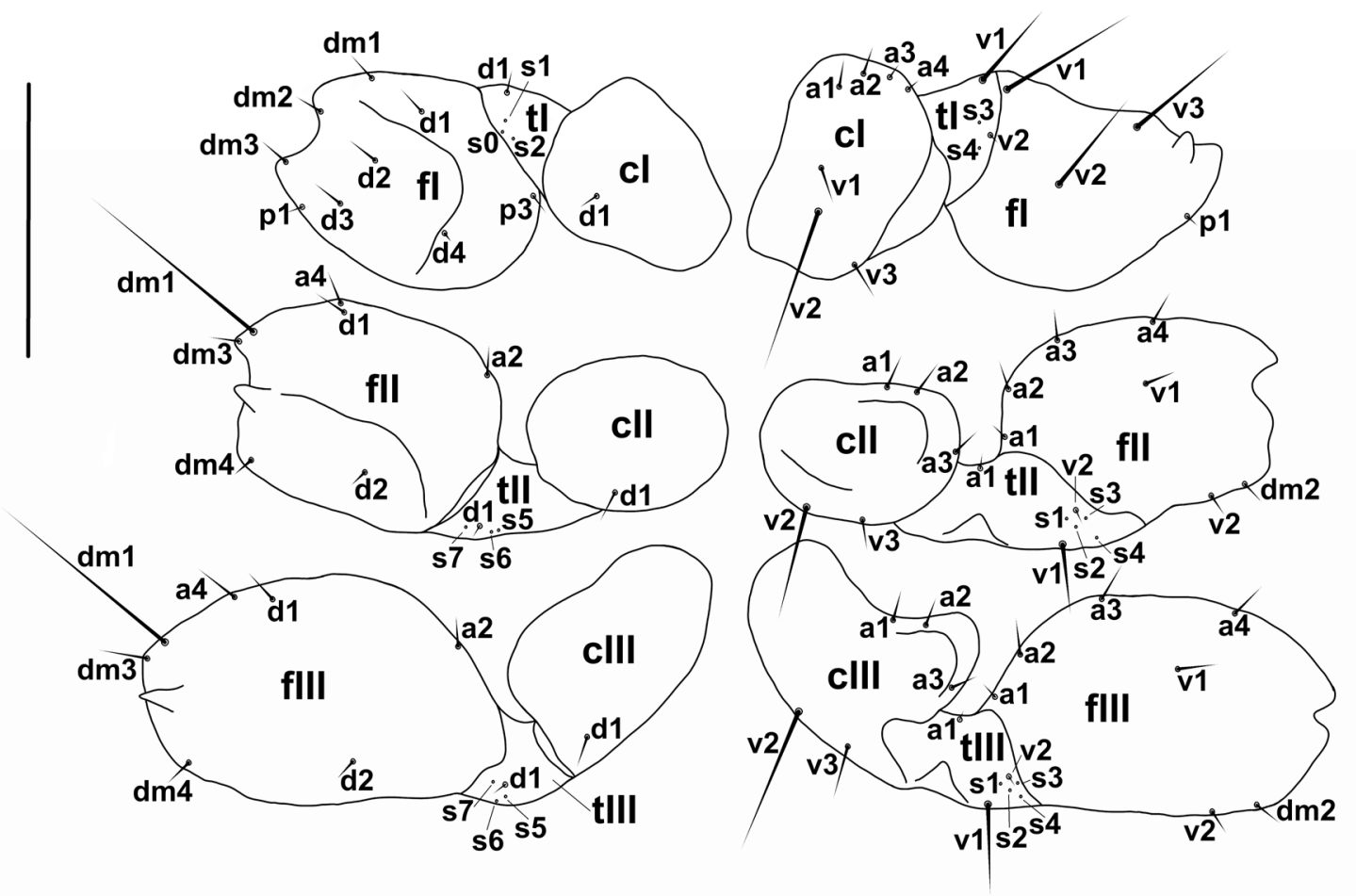

Fig. 5. Philopterus acrocephalus Carriker, 1949 ex Acrocephalus melanopogon (SK25 in MMBC): nomenclature of male leg chaetotaxy, dorsal and ventral views. Abbreviations: $c-$ coxa; $t$ - trochanter; $f$ - femur; $d m$ - distal marginal seta; $d$ - dorsal seta; $a$ - anterior seta; $p$ - posterior seta; $s$ - sensillus; $v-$ ventral seta. Scale bar: $0.1 \mathrm{~mm}$. 
Table 3. Measurements of Philopterus acrocephalus Carriker, 1949 and Philopterus gustafssoni sp. nov. Ranges with mean values in parentheses. Abbreviations: pas - preantennal seta; pcs - preconal seta; $d s m s$ - dorsal submarginal seta; as 3 - third anterior seta; ADPL - anterior dorsal plate length; APLL anterior dorsal plate lateral length; ADPW - anterior dorsal plate width; ANW - anterior notch width; AW - maximal width of abdomen; AL - length of abdomen; GL - male genitalia length; GW - male genitalia width; HL - head length; EWG - external width of genital chamber; IWG - internal width of genital chamber; PAL - preantennal length; PAW - preantennal width; PMCL - premarginal carina length; POL - postantennal length; PTW - pterothorax width; PTL - pterothorax length; PW - prothorax width; SGPW - subgenital plate width; TL - total length; TPVL - tergal plate V length; TRL - trabecula length; TRW - trabecula width; TW - temporal width.

\begin{tabular}{|c|c|c|c|c|}
\hline & \multicolumn{2}{|c|}{ Philopterus acrocephalus } & \multicolumn{2}{|c|}{ Philopterus gustafssoni sp. nov. } \\
\hline & Male & Female & Male & Female \\
\hline pas & $0.0038-0.0100(0.0065)$ & $0.0038-0.0775(0.0104)$ & $0.0550-0.1500(0.0969)$ & $0.0500-0.1325(0.0884)$ \\
\hline$p c s$ & $0.0100-0.0175(0.0126)$ & $0.0075-0.0175(0.0144)$ & $0.0250-0.1100(0.0766)$ & $0.0300-0.1425(0.0820)$ \\
\hline dsms & $0.0975-0.1575(0.1219)$ & $0.0770-0.1600(0.1216)$ & $0.0700-0.2625(0.1540)$ & $0.1000-0.3500(0.1892)$ \\
\hline as 3 & $0.0475-0.0750(0.0637)$ & $0.0500-0.1100(0.0709)$ & $0.0450-0.0725(0.0558)$ & $0.0500-0.0750(0.0631)$ \\
\hline ADPL & $0.1975-0.2275(0.2169)$ & $0.1230-0.2500(0.2231)$ & $0.1800-0.2250(0.2041)$ & $0.2250-0.3225(0.2442)$ \\
\hline APLL & $0.1300-0.1600(0.1463)$ & $0.1510-0.1738(0.1643)$ & $0.1050-0.1975(0.1439)$ & $0.1175-0.1800(0.1568)$ \\
\hline ADPW & $0.1270-0.1375(0.1328)$ & $0.1290-0.1600(0.1489)$ & $0.1050-0.1375(0.1194)$ & $0.1225-0.1575(0.1379)$ \\
\hline ANW & $0.1300-0.1750(0.1633)$ & $0.1610-0.1975(0.1803)$ & $0.0725-0.1225(0.1005)$ & $0.0900-0.1800(0.1175)$ \\
\hline AW & $0.5525-0.6063(0.5887)$ & $0.5480-0.8650(0.6774)$ & $0.5200-0.7800(0.6583)$ & $0.1525-0.9150(0.7352)$ \\
\hline $\mathrm{AL}$ & $0.5450-0.6225(0.5911)$ & $0.6350-0.8425(0.7307)$ & $0.5900-0.9000(0.7539)$ & $0.1925-1.1000(0.8927)$ \\
\hline GL & $0.1600-0.2500(0.2202)$ & & $0.1950-0.2550(0.2218)$ & \\
\hline GW & $0.0550-0.0863(0.0759)$ & & $0.0475-0.0900(0.0782)$ & \\
\hline $\mathrm{HL}$ & $0.4288-0.4938(0.4593)$ & $0.0750-0.5400(0.4635)$ & $0.4200-0.5000(0.4505)$ & $0.4600-0.6200(0.5240)$ \\
\hline EWG & & $0.0813-0.1870(0.0960)$ & & $0.0650-0.0925(0.0786)$ \\
\hline IWG & & $0.0500-0.4020(0.0962)$ & & $0.0325-0.0500(0.0443)$ \\
\hline PAL & $0.1425-0.1650(0.1570)$ & $0.1550-0.1775(0.1676)$ & $0.1725-0.2050(0.1925)$ & $0.1925-0.2250(0.2144)$ \\
\hline PAW & $0.2650-0.3350(0.3036)$ & $0.2980-0.3625(0.3381)$ & $0.3050-0.3600(0.3377)$ & $0.3425-0.5000(0.3925)$ \\
\hline PMCL & $0.0875-0.1125(0.0946)$ & $0.0770-0.1500(0.1026)$ & $0.0900-0.1225(0.1036)$ & $0.1050-0.1325(0.1159)$ \\
\hline POL & $0.2050-0.2900(0.2320)$ & $0.1950-0.3275(0.2553)$ & $0.2025-0.2600(0.2420)$ & $0.2675-0.3100(0.2867)$ \\
\hline PTW & $0.3725-0.4363(0.3950)$ & $0.3590-0.4775(0.4327)$ & $0.1200-0.1925(0.1641)$ & $0.1700-0.2225(0.1958)$ \\
\hline PTL & $0.1410-0.1750(0.1551)$ & $0.1525-0.1850(0.1696)$ & $0.3500-0.4700(0.4186)$ & $0.4100-0.5400(0.4819)$ \\
\hline PW & $0.2600-0.3225(0.2778)$ & $0.2370-0.3225(0.2941)$ & $0.1225-0.1950(0.1480)$ & $0.1250-0.1950(0.1641)$ \\
\hline SGPW & & $0.2850-0.3938(0.3536)$ & $0.1425-0.2700(0.2109)$ & $0.2300-0.4100(0.3284)$ \\
\hline $\mathrm{TL}$ & $1.2575-1.4330(1.3571)$ & $1.4120-1.6825(1.5623)$ & $1.2500-1.6875(1.5000)$ & $1.5750-2.1625(1.8250)$ \\
\hline TPVL & $0.0750-0.1225(0.0957)$ & $0.0930-0.1350(0.1188)$ & $0.1625-0.2500(0.2069)$ & $0.1825-0.2800(0.2279)$ \\
\hline TRL & $0.0975-0.1190(0.1105)$ & $0.0985-0.1275(0.1173)$ & $0.0750-0.1225(0.0955)$ & $0.0700-0.1250(0.1036)$ \\
\hline TRW & $0.0400-0.0500(0.0443)$ & $0.0430-0.0725(0.0495)$ & $0.0325-0.0425(0.0380)$ & $0.0300-0.0500(0.0427)$ \\
\hline TW & $0.4300-0.4588(0.4404)$ & $0.4040-0.5175(0.4846)$ & $0.4200-0.5100(0.4677)$ & $0.1275-0.5600(0.5013)$ \\
\hline
\end{tabular}


subflavescens; MMBC No. 62, 63, $64 \cdot 3$ 우, 1 ○; S Moravian Region, Hodonin District, Hodoninske ponds; 24 Apr. 1949; F. Balat leg.; same host as for preceding; MMBC No. 1410.

SLOVAKIA - 1 q; Bratislava Region, Malacky District, Jakubov; 1 Sep. 1978; F. Balat leg.; ex Acrocephalus arundinaceus; MMBC No. 1501.

\section{Hosts}

\section{Type host}

Acrocephalus arundinaceus arundinaceus (Linnaeus, 1758).

\section{Distribution}

Type locality

Turkmenistan, Kurtlinskoe vodokhranilishche.

\section{Other published location}

Romania (Adam \& Sandor 2004), Grindul Chituc.

\section{Newly reported locations}

Czechia, pond Nesyt, Mlynsky pond, Hodoninske ponds; Slovakia, Jakubov.

\section{Remarks}

The description published by Mey (1983), in our view, contains enough morphological characters for determination of this species. We examined material from Balat's collection (MMBC), which in all morphological features corresponds to this description. Even after several attempts to contact E. Mey and the National Academy of Sciences of Ukraine (where it should be stored), we did not get any information about the type material. Therefore, we could not compare our own examined specimens to the type material and cannot verify identity of the species for $100 \%$.

Philopterus reguli (Denny, 1842)

\section{Material examined}

\section{Holotype}

[UNITED KINGDOM] • + ; H. Denny leg.; ex Regulus regulus; NHML NHMUK010710741, ecat. 8192226.

\section{Misidentified material}

The following additional specimens deposited in NHML are designated as Ph. reguli but in fact they represent some other Ischnocerans not belonging to Philopterus complex:

Ex Troglodytes troglodytes (Linnaeus, 1758) (labeled as Troglodytes vulgaris): 1 ô, collected in 1911 without further specification, other collecting data unknown, NHML NHMUK010646434, ecat. $7988337 \cdot 1$ ô; collected in 1914 without further specification, other collecting data unknown; NHML NHMUK010646435, ecat. 7994159 • 1 क; same collection data as for preceding; NHML NHMUK010646436, ecat. 7996801.

\section{Hosts}

\section{Type host}

Regulus aurocapillus $=$ Regulus regulus regulus (Linnaeus, 1758) - probably it is a straggler from another host. 


\section{Distribution}

Type locality

United Kingdom (without futher specification).

\section{Other published locations}

Ex Regulus regulus - Azerbaijan (Blagoveshtchensky 1940 - as Ph. subflavescens), Bulgaria (Balat 1958), Czechia (Balat 1977), Faroe Islands (Palma \& Jensen 2005), Finland (Hackman 1994), France (Seguy 1944), Germany (Mey 2003), Hungary (Vas et al. 2012b), Kyrgyzstan (Kravtsova 1998), Poland (Złotorzycka 1964, Złotorzycka \& Lucińska 1976), Romania (Bechet 1961), Tajikistan (Blagoveshtchensky 1951 - as Ph. subflavescens), Sweden (Ash 1960), Turkey (Dik et al. 2017), Ukraine (Fedorenko 1987); Ex Regulus ignicapillus - Romania (Negru 1958 and Adam \& Sandor 2004).

\section{Remarks}

Because the name $P h$. reguli appeared to belong to morphologically different species than is commonly found on the type host, it is possible that all the published locations actually refer to Ph. gustafssoni sp. nov. However, none of the above cited publications refers to any concrete specimen, so we are not able to track them and prove their determination.

Philopterus gustafssoni sp. nov. urn:1sid:zoobank.org:act:F1B071D3-5F30-4188-A586-0D511C0DAB58

Figs $6-8 \mathrm{C}$, D, Tables $2-5$

\section{Morphological diagnosis}

Based on descriptions and illustrations published by Mey (1988), Ph. gustafssoni sp. nov. appears to be closely related to $P h$. pallescens, $P h$. rutteri, Ph. hercynicus and $P h$. peripariphilus. With these four species, it shares following morphological characters: (1) broadly triangular head shape with concave frons; (2) trapezoidal anterior dorsal head plate (ADP) with concave anterior margin and heavily sclerotized posterior projection. Anterior part of lateral ADP margin concave, posterior part of lateral ADP margin convex, making all lateral ADP margin S-shaped; (3) three or more pairs of setae on posterior margin of prothorax.

According to what can be seen from the illustrations (Mey 1988), Ph. gustafssoni sp. nov. differs from the abovementioned species in the following combination of characters: (1) lateral margin of preantennal head straight or slightly concave in Ph. gustafssoni sp. nov. (Fig. 6A, C, E), but noticeably concave in Ph. pallescens, Ph. rutteri, Ph. hercynicus and Ph. peripariphilus; (2) frons indented in Ph. gustafssoni sp. nov. (Fig. 6A, C, E) and Ph. hercynicus, but slightly concave in Ph. pallescens, Ph. rutteri and Ph. peripariphilus; (3) postero-lateral ADP corners broadly traingular with more or less right angles in Ph. gustafssoni sp. nov. (Fig. 6A, C, E), but sharp with acute angles in Ph. pallescens, Ph. rutteri, $P h$. hercynicus and Ph. peripariphilus; (4) posterior ADP projection lingulate, relatively narrow on its base and broad on its apex in Ph. gustafssoni sp. nov. (Fig. 6A, C, E), but triangulate with relatively broad base and sharp apex in Ph. pallescens, Ph. rutteri, Ph. hercynicus and Ph. peripariphilus; (5) three pairs of setae on posterior margin of prothorax in Ph. gustafssoni sp. nov. (Fig. 6A, E) and Ph. hercynicus, but more on those of Ph. pallescens, Ph. rutteri and Ph. peripariphilus; (6) three short thorn-like setae on each side of anterior prothorax margin in Ph. gustafssoni sp. nov. (Fig. 6A, E, present also in Ph. acrocephalus, Fig. 4A, E), but absent in Ph. pallescens, Ph. rutteri, Ph. hercynicus and Ph. peripariphilus; (7) ventral head carina with characteristic dark pigmentation in Ph. gustafssoni sp. nov. (Fig. 8C-D), but not pigmented in Ph. pallescens, Ph. rutteri, Ph. hercynicus and Ph. peripariphilus. 
Other body parts than head and prothorax are neither illustrated nor described, so we could not verify how much they differ from Ph. gustafssoni sp. nov. We looked for the type material of Ph. pallescens and $P h$. rutteri in the Natural History Museum, London, United Kingdom (BMNH), where a large part of the Denny's (1842) and Kellogg's (1899) collection is placed. We did found neither specimen of these species nor any Philopterus specimens from the type hosts. Type material of Ph. hercynicus and Ph. peripariphilus should be deposited in the Museum of Natural History Rudolstadt, Germany. We tried to contact Eberhard Mey in order to get more information about this material, but without any success. From Balat's collection (MMBC) we examined one female paratype of Ph. peripariphilus and one female from Periparus ater (Linnaeus, 1758) labeled as Ph. pallescens. Both these specimens correspond to all the characters of each species described by Mey (1988) but we hesitate to assess relevance of these species only on base of one specimen. Hence, we are leaving identity of all the four species unresolved and provide only description of Ph. gustafssoni sp. nov.

\section{Etymology}

The specific epithet is a patronym in honor of Dr. Daniel R. Gustafsson, for his exceptional contribution to worldwide knowledge of chewing lice and leading of chewing lice frontier research in China.

\section{Material examined}

\section{Holotype}

CZECHIA - § (Fig. 8C); Moravian-Silesian Region, Frydek-Mistek District, Janovice; 49 $37^{\prime} \mathrm{N}$, 18²4'E; 19 Mar. 2015; I. Literak leg.; ex Regulus regulus regulus; MMBC CZ-OS01.

\section{Paratypes}

CZECHIA $・ 1$; ; same collection data as for preceding; MMBC CZ-OS01・10, 1 ; ; same collection data as for preceding; MMBC CZ-OS02 $\bullet 1 \hat{\jmath}, 1$; ; same collection data as for preceding; MMBC CZ$\mathrm{OS} 03 \cdot 1 \hat{0}, 1$ + ; same collection data as for preceding; MMBC CZ-OS04.

\section{Other material}

CZECHIA • $18 \odot \odot$; same collection data as for preceding; MMBC • $13 \odot \odot$; S Bohemian Region, Jindrichuv Hradec District, Klec; $49^{\circ} 05^{\prime} \mathrm{N}, 1^{\circ} 44^{\prime} \mathrm{E}$; $15-16$ May 2015; same collector, and host as for

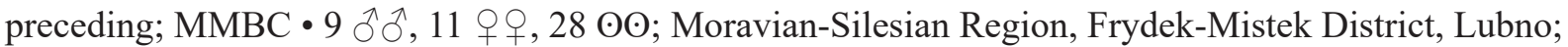
$49^{\circ} 36^{\prime} \mathrm{N}, 18^{\circ} 22^{\prime} \mathrm{E}$; 18 Mar. and 15-16 Apr. 2015; same collector and host as for preceding; MMBC - 1 +; S Moravian Region, Brno Country District, Skalicka; 49²1'N, 16³0'E; 2 Oct. 2015; same

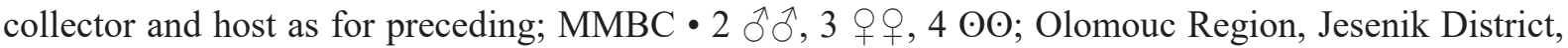
Zulova; $50^{\circ} 18^{\prime} \mathrm{N}, 17^{\circ} 05^{\prime} \mathrm{E}$; 8 and 10 Nov. 2014; same collector and host as for preceding; MMBC • 2 우, $5 \odot \odot$; S Moravian Region, Brno Country District, Moravske Kninice; 49 $17^{\prime} \mathrm{N}, 16^{\circ} 29^{\prime} \mathrm{E}$; 21 Dec. 2009; O. Sychra \& I. Literak leg.; same host as for preceding; MMBC • 1 q, $4 \odot \odot$; S Bohemian Region, Jindrichuv Hradec District, Klec; 490ํN, 1444'E; 16 May 2015; I. Literak leg.; ex Regulus ignicapillus; specimen lost during DNA extraction.

UNITED KINGDOM • 1 ภ, 2 우, 1 ¡; England, Dorset, Portland Bill, Portland Bird Observatory; 15 Apr. 1975; ex Regulus ignicapillus; NHML NHMUK010647797-98, Brit. Mus. 1975-355 • 1 §̄,

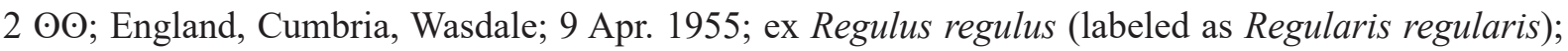
NHML NHMUK010647799, Brit. Mus. 1955-233・1 $ð, 2$ 우; England, Lancashire, Southport; 5 Mar. 1961; ex Regulus regulus; NHML NHMUK010647803, Brit. Mus. 1961-671 • 1 +, 1 @; England, Surrey; Oct. 1973; K. M. Barralet; same host as for preceding; NHML NHMUK010647804.

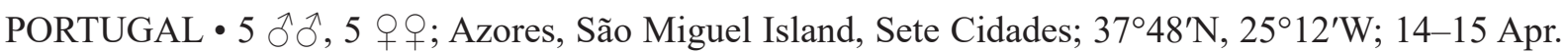
2013; I. Literak leg.; ex Regulus regulus azoricus; MMBC. 


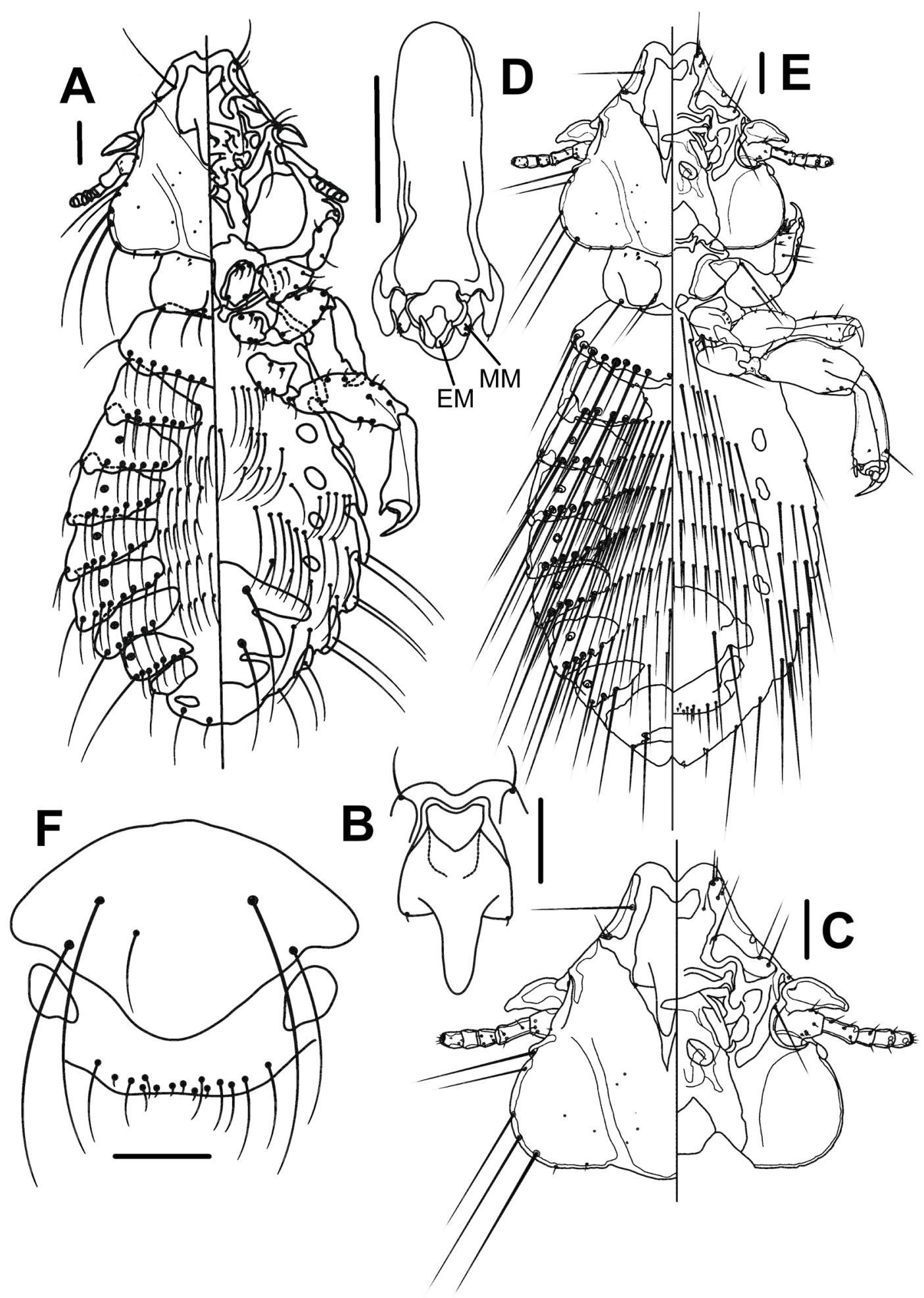

Fig. 6. Philopterus gustafssoni sp. nov. ex Regulus regulus (MMBC CZ-OS01): A. Male habitus, dorsal and ventral views. B. Male dorsal anterior plate (ADP), dorsal view. C. Female head, dorsal and ventral views. D. Male genitalia, ventral view. E. Female habitus, dorsal and ventral views. F. Female subgenital plate, vulval margin, and ventral terminalia, ventral view. Abbreviations: EM - endomere; MM - mesomere.Scale bars: $0.1 \mathrm{~mm}$. 


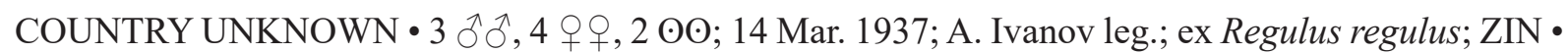

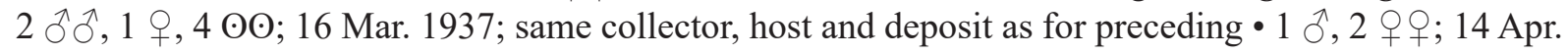
1948; Lyubin leg.; same host as for preceding; ZIN.

POLAND • 1 ð’; Pomeranian Voivodeship, Nowy Dwor Gdanski County, Mierzeja Wislana; 1 Apr. 1966; Busse leg.; same host as for preceding; MNHW 9/a/58 • 1 क ; same collection data as for preceding; MNHW 9/a/59 • 1 q; same location, collector and host as for preceding; 2 Apr. 1966; MNHW 9/a/60 • 1 + ; same collection data as for preceding; MNHW 9/a/61 • $1 \odot$ [labeled as + ]; same location, collector and host as for preceding; 25 Apr. 1966; MNHW 9/a/62 • 1 ک ; same location, collector and host as for preceding; 1 Apr. 1966; MNHW 9/a/63 • $1 \odot$; same collection data as for preceding; MNHW 9/a/64 - 1 ○; same location, collector and host as for preceding; 2 Apr. 1966; MNHW 9/a/65 • $1 \odot$; same location, collector and host as for preceding; 1 Apr. 1966; MNHW 9/a/66 • $1 \odot$; same location, collector and host as for preceding; 4 Apr. 1966; MNHW 9/a/67 $1 \odot$; same location, collector and host as for preceding; 1 Apr. 1966; MNHW 9/a/68 • 1 q; same location, collector and host as for preceding; 8 Apr. 1966; MNHW 9/a/69 • 1 क; same collection data as for preceding; MNHW 9/a/70 • $1 \odot$; Pomeranian Voivodeship, Puck County, Hel; 10 Sep. 1962; same collector and host as for preceding; MNHW 9/a/1

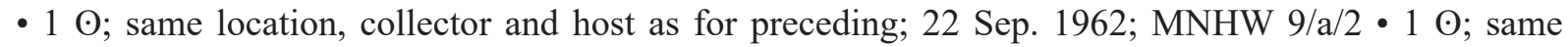
location, collector and host as for preceding; 26 Apr. 1963; MNHW 9/a/5 • $1 \odot$; same collection data as for preceding; MNHW 9/a/6 • $1 \odot$; same location, collector and host as for preceding; 14 Apr. 1963; MNHW 9/a/7 • $1 \odot$; same collection data as for preceding; MNHW 9/a/8 $\bullet 1 \odot$; same location, collector and host as for preceding; 1 May 1963; MNHW 9/a/9 • $1 \odot$; same collection data as for preceding; MNHW 9/a/10 • $1 \odot$; same location, collector and host as for preceding; 15 Apr. 1963; MNHW 9/a/11 • $1 \odot$; same collection data as for preceding; MNHW 9/a/12 • $1 \odot$; same collection data as for preceding; MNHW 9/a/13 • 1 q; same location, collector and host as for preceding; 14 Apr. 1963; MNHW 9/a/14 - 1 ठ̊; same location, collector and host as for preceding; 16 Apr. 1963; MNHW 9/a/15 • 1 क; same location, collector and host as for preceding; 27 Apr. 1965; MNHW 9/a/16 • 1 \%; same collection data as for preceding; MNHW 9/a/17 • $1 \odot$; same location, collector and host as for preceding; 1 Apr. 1965; MNHW 9/a/18 • 1 q; same location, collector and host as for preceding; 20 Apr. 1965; MNHW 9/a/19 - 1 O ; same location, collector and host as for preceding; 3 Apr. 1965; MNHW 9/a/20 • 1 क; same collection data as for preceding; MNHW 9/a/21 1 1 ; same collection data as for preceding; MNHW 9/a/22 • $1 \odot$; same collection data as for preceding; MNHW 9/a/23 $1 \odot$; same collection data as for preceding; MNHW 9/a/24 $1 \odot$; same collection data as for preceding; MNHW 9/a/25 • 1 o; same location, collector and host as for preceding; 17 Apr. 1965; MNHW 9/a/27 • $1 \odot$; same collection data as for preceding; MNHW 9/a/28 • $1 \odot$; same collection data as for preceding; MNHW 9/a/29 • 1 \%; same location, collector and host as for preceding; 29 Mar. 1965; MNHW 9/a/30 • 1 ; ; same location, collector and host as for preceding; 25 Mar. 1965; MNHW 9/a/31 • $1 \odot$; same location, collector and host as for preceding; 29 Mar. 1965; MNHW 9/a/32 • 1 o; same location, collector and host as for preceding; 17 Apr. 1965; MNHW 9/a/35 • 1 9 ; same collection data as for preceding; MNHW 9/a/36 • $1 \odot$; same collection data as for preceding; MNHW 9/a/37 • $1 \odot$; same collection data as for preceding; MNHW 9/a/38 • 1 क; same location, collector and host as for preceding; 3 Apr. 1965; MNHW 9/a/39 - 1 ๑; same location, collector and host as for preceding; 2 Apr. 1965; MNHW 9/a/40 • 1 o; same location, collector and host as for preceding; 17 Apr. 1965; MNHW 9/a/43 11 q; same collection data as for preceding; MNHW 9/a/44 • $1 \odot$; same collection data as for preceding; MNHW 9/a/45 • 1 \%; same collection data as for preceding; MNHW 9/a/47 $1 \odot$; same location, collector and host as for preceding; 3 Apr. 1965; MNHW 9/a/48 • $1 \odot$; same collection data as for preceding; MNHW 9/a/49 • 1 क; same collection data as for preceding; MNHW 9/a/50 • $1 \odot$; same location, collector and host as for preceding; 17 Apr. 1965; MNHW 9/a/53 • $1 \odot$; same collection data as for preceding; MNHW 9/a/54 • 1 $\odot$; same location, collector and host as for preceding; 3 Apr. 1965; MNHW 9/a/55 • $1 \odot$; same collection data as for preceding; MNHW 9/a/56 • $1 \odot$; same collection data as for preceding; MNHW 9/a/57 • 1 §; Pomeranian Voivodeship, Nowy Dwor Gdanski County, Mierzeja Wislana; 1 Apr. 1966, same collector 
and host as for preceding; MNHW 9/a/58 • 1 q; same collection data as for preceding; MNHW 9/a/59 1 $\rightarrow$; same location, collector and host as for preceding; 2 Apr. 1966; MNHW 9/a/60 • 1 \% ; same collection data as for preceding; MNHW 9/a/61 - $1 \odot$; same location, collector and host as for preceding; $25 \mathrm{Apr}$. 1966; MNHW 9/a/62 • 1 ऊ; same location, collector and host as for preceding; 1 Apr. 1966; MNHW 9/a/63 • $1 \odot$; same location, collector and host as for preceding; 2 Apr. 1966; MNHW 9/a/65 • $1 \odot$; same location, collector and host as for preceding; 1 Apr. 1966; MNHW 9/a/66 • $1 \odot$; same location, collector and host as for preceding; 4 Apr. 1966; MNHW 9/a/67 • 1 ○; same location, collector and host as for preceding; 1 Apr. 1966; MNHW 9/a/68 • 1 क ; same location, collector and host as for preceding; 8 Apr. 1966; MNHW 9/a/69 • 1 क; same collection data as for preceding; MNHW 9/a/70 • $1 \mathrm{o}^{\top}$; Pomeranian Voivodeship, Puck County, Hel; 25 Apr. 1969; same collector and host as for preceding; MNHW 9/a/73 - 1 $\mathrm{J}_{\text {; }}$ same collection data as for preceding; MNHW 9/a/74 • 1 q; same location, collector and host as for preceding; 21 Apr. 1969; MNHW 9/a/75 • 1 \%; same collection data as for preceding; MNHW 9/a/77(2) • $1 \odot$; same location, collector and host as for preceding; 25 Apr. 1969; MNHW 9/a/78(2) • 1 $\odot$; same collection data as for preceding; MNHW 9/a/79(2) • $1 \odot$; same collection data as for preceding; MNHW 9/a/80(2) • $1 \odot$; same location, collector and host as for preceding; 17 Apr. 1969; MNHW 9/a/82(3) • 1 त ; same collection data as for preceding; MNHW 9/a/84 $\bullet 1$; ; same collection data as for preceding; MNHW 9/a/86 • $1 \odot$; same collection data as for preceding; MNHW 9/a/88(1) • $1 \odot$; same location, collector and host as for preceding; 21 Apr. 1969; MNHW 9/a/100(2) •1 $\odot$; same collection data as for preceding; MNHW 9/a/100(2) [the same label as preceding] • $1 \odot$; same collection data as for preceding; MNHW 9/a/108(1) • $1 \odot$; same collection data as for preceding; MNHW 9/a/109(1) • $1 \odot$; same collection data as for preceding; MNHW 9/a/110(4) • 1 ; ; same location, collector and host as for preceding; 14 Apr. 1969; MNHW 9/a/112(2) 1 \% ; same location, collector and host as for preceding; 17 Apr. 1962; MNHW 9/a/113(2) • 1 क; same location, collector and host as for preceding; 21 Apr. 1969; MNHW 9/a/119(2)・ 1 q; same collection data as for preceding; MNHW 9/a/120(2)・ 1 q; same location, collector and host as for preceding; 16 Apr. 1969; MNHW 9/a/122(1) • $1 \odot$; same collection data as for preceding; MNHW 9/a/129 • 1 क; same location, collector and host as for preceding; 21 Apr. 1969; MNHW 9/a/131(4) • 1 đ’; same location, collector and host as for preceding; 31 Apr.[?] 1965; MNHW 9/a/133 • 1 क ; same location, collector and host as for preceding; 21 Apr. 1969; MNHW 9/a/135(3) • $1 \odot$; same collection data as for preceding; MNHW 9/a/136 • $1 \odot$; same collection data as for preceding; MNHW 9/a/137(4) • $1 \odot$; same collection data as for preceding; MNHW 9/a/157(3) • $1 \odot$; same collection data as for preceding; MNHW 9/a/159(3). 1 1 ; same locality as for preceding; 16 Apr. 1969; Busse leg.; ex Regulus ignicapillus; MNHW 9/b/1.

AZERBAIJAN • 1 ภ, 1 क; Lankaran District; 10 Mar. 1934; Shtroi leg.; ex Regulus regulus buturlini;

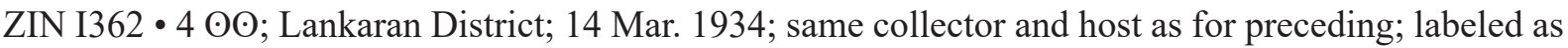
Philopterus subflavescens (determined by D.I. Blagoveshtchensky); ZIN I400.

UZBEKISTAN • 1 ô, 1 क; 16 Jan. 1940; ex Regulus regulus tristis; ZIN I445-22 • 2 q $q$; same collection data as for preceding; ZIN I446-23.

Additional material collected

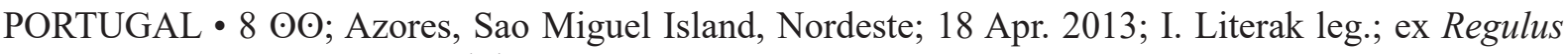

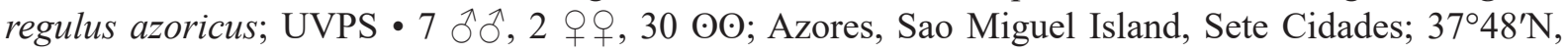
$25^{\circ} 12^{\prime} \mathrm{W}$; 15 Apr. 2013; same collector and host as for preceding; UVPS • 1 \%; Azores, Santa Maria Island, Pico Alto; $36^{\circ} 58^{\prime}$ N, $25^{\circ} 05^{\prime}$ W; 20 Sep. 2013; O. Sychra \& I. Literak leg.; ex Regulus regulus sanctaemariae; UVPS.

\section{Not determinable material}

The following material from Złotorzycka's collection is probably Ph. gustafssoni sp. nov., but the species could not be determined because it contained only larvae without any associated adult lice: 
POLAND • 1 ๑; Pomeranian Voivodeship, Nowy Dwor Gdanski County, Mierzeja Wislana; 26 Sep. 1965; Busse leg.; ex Regulus regulus; MNHW 9/a/26 • $1 \odot$; same location, collector and host as for preceding; 30 Sep. 1964; MNHW 9/a/40 • $1 \odot$; same collection data as for preceding; MNHW 9/a/41 • 1 $\odot$; same collection data as for preceding; MNHW 9/a/42 • $1 \odot$; same location, collector and host as for preceding; 1 Apr. 1960; MNHW 9/a/64 • 1 ○; Pomeranian Voivodeship, Nowy Dwor Gdanski County, Skowronki; 3 Sep. 1962; J. Złotorzycka leg.; same host as for preceding; MNHW 9/a/3 • 1 ○; same location, collector and host as for preceding; 9 Sep. 1962; MNHW 9/a/4.

\section{Description}

\section{Both sexes}

Head as in Fig. 6C, broadly triangular, at least as wide as long, with frons deeply concave, preantennal region shorter than the postantennal, with straight lateral margin. Hyaline margin slight, not wider than frons, in some specimens barely apparent. Dorsal anterior head preantennal plate (ADP) as in Fig. 6B, with anterior margin centrally deeply indented or concave and straight anterior part of lateral margin. Posterior part of ADP lateral margin convex, so entire ADP (ignoring central posterior projection) trapezoidal with convex lateral margins. Large heavily sclerotized posterior projection protruding from posterior part of ADP, with a base the same width as anterior ADP margin. Postero-lateral corners of ADP broadly triangular, with bases positioned approximately at the level of $1 / 4$ of length of the central projection, about the same width as the central projection at this level, both postero-lateral ADP angles more or less right, very weakly sclerotized and therefore barely apparent, especially in comparison with

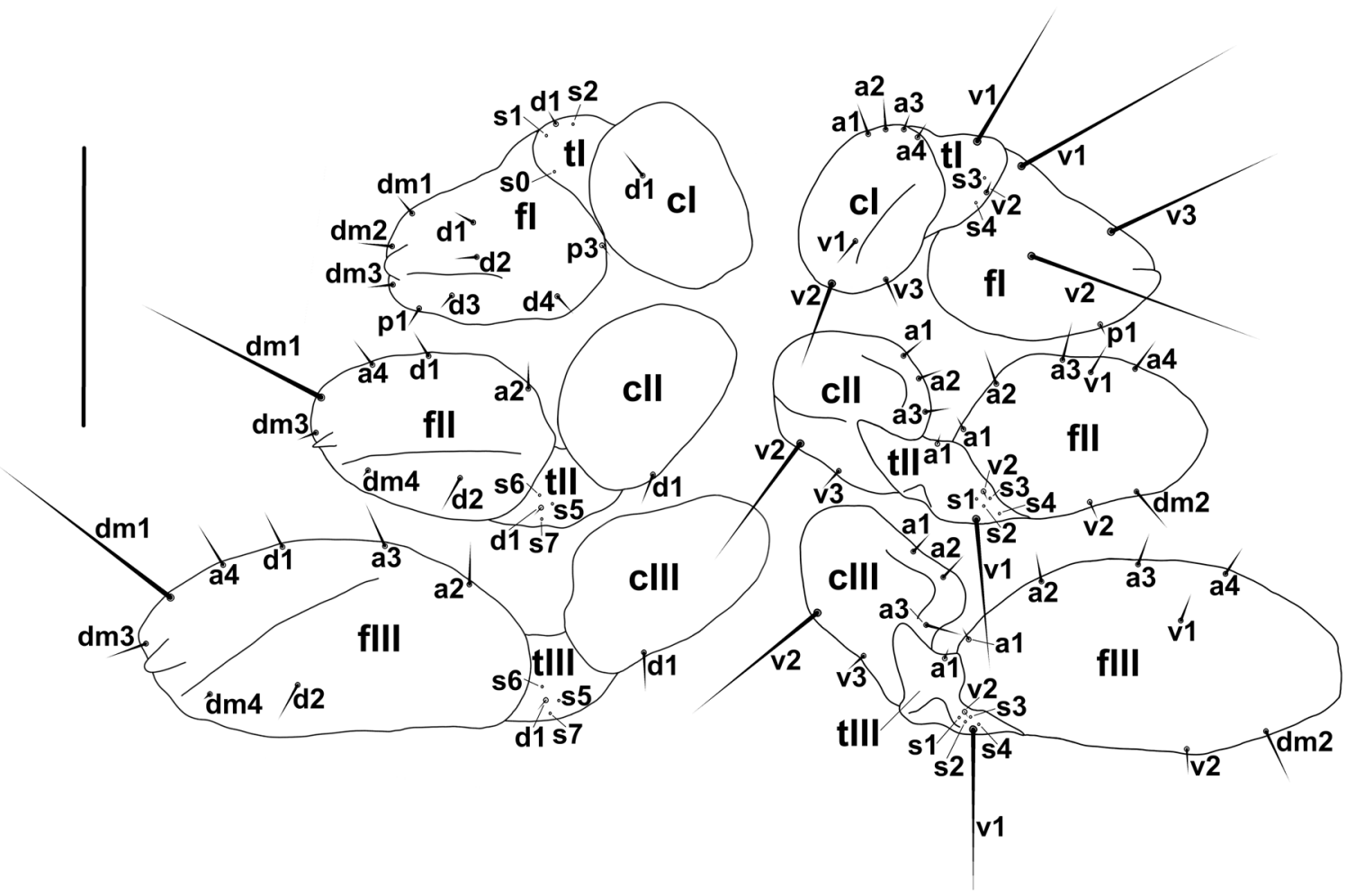

Fig. 7. Philopterus gustafssoni sp. nov. ex Regulus regulus (MMBC CZ-OS01): nomenclature of male leg chaetotaxy, dorsal and ventral views. Abbreviations: $c$ - coxa; $t$ - trochanter; $f$ - femur; $d m-$ distal marginal seta; $d$ - dorsal seta; $a$ - anterior seta; $p$ - posterior seta; $s$ - sensillus; $v$ - ventral seta. Scale bar: $0.1 \mathrm{~mm}$. 
the central projection. There is no or only a very slight indentation between the ADP postero-lateral corners and the central projection. Ventral anterior plate as in Fig. 6C, lateral quarters of anterior margin straight as well as lateral margins, straight or slightly convex posterior margins converging into one central median point, so the entire posterior $1 / 2$ of the ventral plate seems a wide triangular jag. Ventral carina darkly pigmented, creating characteristic pied pattern on preantennal head (Fig. 8C-D). Prothorax as in Fig. 6A, E, with 1 medium-long pps in each postero-lateral corner, 2 medium-long pps on each side of posteriorly convergent central part of posterior margin and 3 short thorn-like setae on each side of its anterior margin. Prosternum elongated and posteriorly fused with anterior part of rhombic mesosternum. In place of metasternum 1-2 medium-long setae on each side. Pterothorax with 10-13 medium-long posterior setae $(\mathrm{mts})$ on each side, all of them about the same length. Lateral margins of pterothorax with bulging anterior part, posterior margin with noticeable bulge in places where it overlaps with tergopleurites II on each side. Tergopleurites II-IX with all setae the same length, short or medium-long, never reaching posterior margin of following segment. Leg chaetotaxy as in Fig. 7, measurements as in Table 3.

\section{Male}

Habitus as in Fig. 6A, thoracic and abdominal chaetotaxy as in Fig. 6A and Table 2. Sternal setae (sts) medium-long on segments II-IV and VI, slightly overreaching posterior margin of following segments, and long on segment V, overreaching anterior margin of subgenital plate. Subgenital plate as in Fig. 6A, with large central anterior bulge, formed from sternites VII-IX, which are fused only in narrow central parts, in most of their width remaining separated by deep lateral indentations. Posterior margin of subgenital plate widely concave, 1 long (reaching to the posterior end of the body) seta on each side of posterior margin of original sternite VII and 1 about the same length (noticeably overreaching posterior body end) on each side of posterior margin of original sternite VIII, all 4 setae placed more or less medioanteriorly from the median ends of lateral indentations. Genitalia as in Fig. 6D, basal apodeme long with rounded anterior margin fluently flowing into straight lateral margins. Parameres finger-like, clearly separated from the basal plate, relatively short, never overreaching elongated mesosome, never touching each other if turned medianly, either without or with only 1 sensilla on the distal end. Mesomeres (MM in Fig. 6D) and endomeres (EM in Fig. 6D) fully developed, clearly separated from the basal plate. Mesomeres relatively short and wide, with 3 sensillae on each distal end, which reach approximately to the same level as distal end of parameres. Endomeres claviform, with bulbous wider parts distally.

\section{Female}

Habitus as in Fig. 6E, head as in Fig. 6C, in general as in male, except following features. Thoracic and abdominal chaetotaxy as in Fig. 6E and Table 2. Sternal setae (sts) on all segments long, reaching at least to posterior margin of following segment. Subgenital plate (Fig. 6F) with rounded anterior margin, formed from sternite VII and large triangular central part of sternite VIII, posterior margin of which is composed of 2 posteriorly converging lines and gives the whole plate more or less the appearance of a pie wedge with rounded posterior apex. Lateral parts of sternite VIII separated as vestigial sternites, which are triangular or piriform, placed postero-laterally from the subgenital plate. Subgenital plate with 2 very long setae on each side, 1 placed on the supposed border of original sternites VII and VIII, 1 more anteriorly and medially, placed more or less in center of corresponding half of plate, both reaching always beyond vulval margin. Sometimes, there may be 1 medium-long seta placed on each side on the presumed border of original sternites, medially from the abovementioned long seta. Vulval margin as in Fig. 6F, straight in median part, with both lateral parts flexed anteriorly, fringed by 3-5 medium-long setae in each lateral part and by 6-8 short setae in the median part. Inner genital sclerites missing.

\section{Hosts}

\section{Type host}

Regulus regulus regulus (Linnaeus, 1758). 


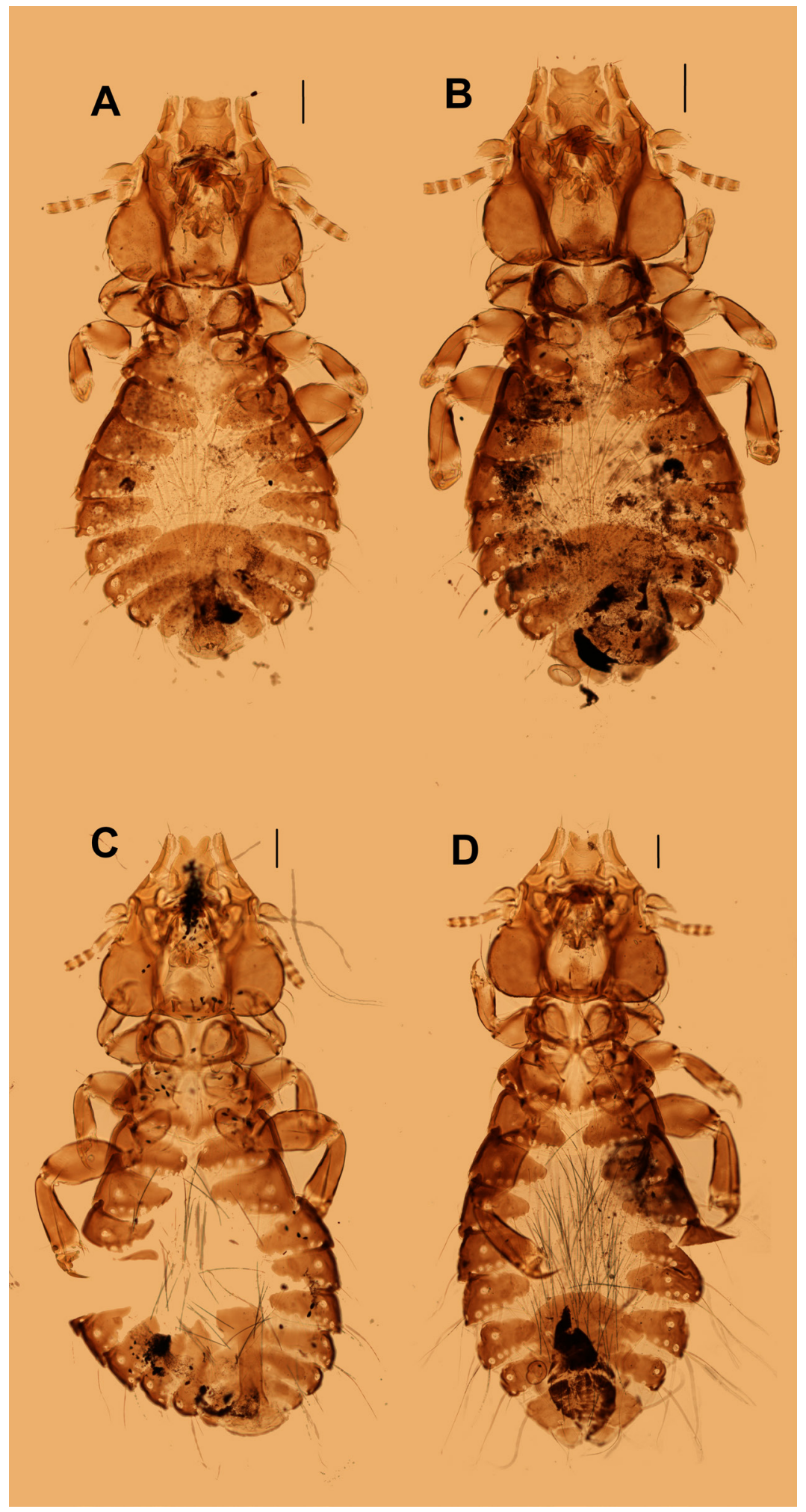

Fig. 8. A-B. Philopterus acrocephalus Carriker, 1949 ex Acrocephalus melanopogon: A. Herein described and illustrated male (MMBC SK25), dorsal view. B. Herein described and illustrated female (MMBC SK25), dorsal view. - C-D. Philopterus gustafssoni sp. nov. ex Regulus regulus: C. Holotype (MMBC CZ-OS01), dorsal view. D. Herein described and illustrated female paratype (MMBC CZ-OS01), dorsal view. Scale bars: $0.1 \mathrm{~mm}$. 
Table 4. Average intraspecific p-distances of examined specimens of Philopterus acrocephalus Carriker, 1949, Philopterus gustafssoni sp. nov., Philopterus citrinellae (Schrank, 1776) and Philopterus fringillae (Scopoli, 1772) computed from COI, hyp, TMEDE and concatenated gene sequences.

\begin{tabular}{lccccc}
\hline Species & $\mathbf{n}$ & COI & hyp & TMEDE6 & concatenated \\
\hline Philopterus acrocephalus & 2 & 0 & 0 & 0 & 0 \\
Philopterus gustafssoni sp. nov. & 4 & 0.030 & 0.003 & 0.003 & 0.014 \\
Philopterus citrinellae & 6 & 0.063 & 0 & 0.004 & 0.025 \\
Philopterus fringillae & 2 & 0 & 0.003 & 0 & 0.001 \\
\hline
\end{tabular}

\section{Other hosts}

Regulus regulus (Linnaeus, 1758), Regulus regulus azoricus Seebohm, 1883, Regulus regulus buturlini von Loudon, 1911, Regulus regulus sanctaemariae Vaurie, 1954, Regulus regulus tristis Pleske, 1892, Regulus ignicapillus (Temminck, 1820).

\section{Type location}

Czechia, Janovice.

\section{Other locations}

Czechia, Klec, Lubno, Moravske Kninice, Skalicka, Zulova; United Kingdom, Portland Bird Observatory, Southport, Surrey, Wasdale; Portugal, Azores, Sao Miguel, Santa Maria; Azerbaijan, Lankaran District; Uzbekistan, specific location unreadable.

\section{Remarks}

The odd medium-long seta shown in the left part of the female subgenital plate (Fig. 6F) is not always present. Here it is included in the illustration because it is present in the specimen used for the drawing.

\section{Genetic diversity}

Two specimens of Ph. gustafssoni sp. nov. from Regulus regulus regulus (collected in Czechia), one specimen from Regulus regulus azoricus and one specimen from Regulus ignicapillus were genetically analysed, providing sequences of all three genes examined. Since samples from two host species (and in the case of goldcrest, Regulus regulus, even from its two subspecies) were analysed, the relatively noticeable intraspecific genetic variability in Ph. gustafssoni sp. nov. (3.0\% for COI, 0.3\% for $h y p, 0.3 \%$ for TMEDE6 and $1.4 \%$ for the concatenated sequences) was also recorded; for more details and comparison with intraspecific variability of the other species mentioned above, see Table 4. From the Philopterus species from which we managed to get molecular data (Najer, unpublished results), following three species are the nearest relatives of Ph. gustafssoni sp. nov.: Ph. acrocephalus - net interspecific $p$-distances $23.1 \%$ for COI, $1.6 \%$ for hyp, $0.8 \%$ for TMEDE6 and $9.7 \%$ for the concatenated sequences, Ph. fringillae $-18.0 \%$ for COI, $1.6 \%$ for hyp, $0.4 \%$ for TMEDE6 and $7.6 \%$ for the concatenated sequences, and Ph. citrinellae $-14.8 \%$ for COI, $1.6 \%$ for hyp, $0.4 \%$ TMEDE6 and $6.4 \%$ for the concatenated sequences); more details are given in Table 5 .

\section{Discussion}

As we already mentioned, the most recent descriptions of Philopterus from Acrocephalidae and Regulidae (Złotorzycka 1964; Złotorzycka \& Lucińska 1976) are not sufficient for clear morphological diagnosis of these species. Their insufficiency consists mainly in too general morphological characteristics 
Table 5. Net interspecific p-distances of Philopterus acrocephalus Carriker, 1949, Philopterus gustafssoni sp. nov., Philopterus citrinellae (Schrank, 1776) and Philopterus fringillae (Scopoli, 1772) computed from COI, hyp, TMEDE and concatenated gene sequences.

\begin{tabular}{lcccc}
\hline COI & Ph. acrocephalus & $\begin{array}{r}\text { Ph. gustafssoni } \\
\text { sp. nov. }\end{array}$ & Ph. citrinellae & Ph. fringillae \\
\hline $\begin{array}{l}\text { Philopterus acrocephalus } \\
(\mathrm{n}=2)\end{array}$ & 0.231 & 0.198 & 0.245 \\
$\begin{array}{l}\text { Philopterus gustafssoni } \\
\text { sp. nov. (n=4) }\end{array}$ & 0.231 & 0.148 & 0.180 \\
$\begin{array}{l}\text { Philopterus citrinellae } \\
(\mathrm{n}=6)\end{array}$ & 0.198 & 0.148 & & 0.189 \\
$\begin{array}{l}\text { Philopterus fringillae } \\
(\mathrm{n}=2)\end{array}$ & 0.245 & 0.180 & 0.189 & \\
\hline
\end{tabular}

\begin{tabular}{lcccc}
\hline hyp & Ph. acrocephalus & $\begin{array}{r}\text { Ph. gustafssoni } \\
\text { sp. nov. }\end{array}$ & Ph. citrinellae & Ph. fringillae \\
\hline $\begin{array}{l}\text { Philopterus acrocephalus } \\
(\mathrm{n}=2)\end{array}$ & 0.016 & 0.018 & 0.018 \\
$\begin{array}{l}\text { Philopterus gustafssoni } \\
\text { sp. nov. (n=4) }\end{array}$ & 0.016 & 0.016 & 0.016 \\
$\begin{array}{l}\text { Philopterus citrinellae } \\
\text { (n=6) }\end{array}$ & 0.018 & 0.016 & & 0.016 \\
$\begin{array}{l}\text { Philopterus fringillae } \\
(\mathrm{n}=2)\end{array}$ & 0.018 & 0.016 & 0.016 & \\
\hline
\end{tabular}

\begin{tabular}{lcccc}
\hline TMEDE6 & Ph. acrocephalus & $\begin{array}{c}\text { Ph. gustafssoni } \\
\text { sp. nov. }\end{array}$ & Ph. citrinellae & Ph. fringillae \\
\hline $\begin{array}{l}\text { Philopterus acrocephalus } \\
(\mathrm{n}=2)\end{array}$ & 0.008 & 0.012 & 0.014 \\
$\begin{array}{l}\text { Philopterus gustafssoni } \\
\text { sp. nov. (n=4) }\end{array}$ & 0.008 & 0.004 & 0.004 \\
$\begin{array}{l}\text { Philopterus citrinellae } \\
\text { (n=6) }\end{array}$ & 0.012 & 0.004 & & 0.009 \\
$\begin{array}{l}\text { Philopterus fringillae } \\
(\mathrm{n}=2)\end{array}$ & 0.014 & 0.004 & 0.009 & \\
\hline $\begin{array}{l}\text { concatenated } \\
\text { Philopterus acrocephalus } \\
(\mathrm{n}=2)\end{array}$ & Ph. acrocephalus & $\begin{array}{c}\text { Ph. gustafssoni } \\
\text { sp. nov. }\end{array}$ & Ph. citrinellae & Ph. fringillae \\
$\begin{array}{l}\text { Philopterus gustafssoni } \\
\text { sp. nov. (n=4) }\end{array}$ & 0.097 & 0.097 & 0.086 & 0.105 \\
$\begin{array}{l}\text { Philopterus citrinellae } \\
(\mathrm{n}=6)\end{array}$ & 0.086 & 0.064 & 0.064 & 0.076 \\
$\begin{array}{l}\text { Philopterus fringillae } \\
\text { (n=2) }\end{array}$ & 0.105 & 0.076 & 0.081 & 0.081 \\
\hline
\end{tabular}


and illustrations. As a result, when one gets any Philopterus specimens from family Acrocephalidae or Regulidae, they often key to several, if not all, species described in the aforementioned papers. Furthermore, often it is rather difficult to clearly define differences between particular species, and this might cause the impression that the new species descriptions were based solely on the presumption of strict host specificity. Another case of insufficient descriptions is represented by two names which were used without any obvious attemps of delimitation - Philopterus subflavescens (Geoffroy, 1762) and Docophorulus communis (Nitzsch in Burmeister 1838).

As explained by Clay \& Hopkins (1950: 269), the names used by Geoffroy (1762, including Ph. subflavescens) are not binominal, being rather descriptive phrases, and therefore they are invalid. Nevertheless, the name $P h$. subflavescens has been incorrectly used as a valid species commonly occurring on passerines (e.g., Balat 1953; Bechet 1956; Blagoveshtchensky 1940, 1951). Peters (1936) reported $P h$. subflavescens from 42 birds and noted that this is due to the fact that insufficient attention had been given to differentiating variations in the parasite that might be sufficient to establish new species or varieties. It seems that any philopterid louse found on passerines was named by this name in the past (Clay \& Hopkins 1950; Sychra et al. 2014b).

Concerning Acrocephalidae and Regulidae, Ph. subflavescens was reported from oriental reedwarbler, Acrocephalus orientalis (Temminck \& Schlegel, 1847) (Uchida 1948), A. a. arundinaceus and A. scirpaceus (Balat 1953) and Regulus regulus (Blagoveshtchensky 1940, 1951). Uchida (1948) synonymized Ph. subflavescens with Docophorulus communis (Nitzsch in Burmeister 1838).

The original description of $D$. communis consists of only a few words; however, this name was also previously known from a vast number of host species (Burmeister 1838; Denny 1842; Giebel 1874; Piaget 1880; Kellog 1896; Uchida 1917, 1948) including Acrocephalus (Paz Martin-Mateo \& Jimenez Millan 1967 reported Philopterus communis from A. schoenobaenus). Uchida (1948) also placed this species into his newly erected genus Bitrabeculus Uchida, 1948, which should be morphologically distinguished according to "two pairs of trabeculae". Within the same genus he also described Bitrabeculus mitsusui Uchida, 1948, which was later moved to genus Philopteroides (Mey 2004), so he apparently considered the large coni as second trabeculae. Price et al. (2003) presented D. communis (named as Philopterus, referring to Hopkins \& Clay 1952) as a synonymy of Ph. citrinellae.

Since we confirmed Ph. acrocephalus as a native parasite of several species of Acrocephalidae we suggest that all lice previously reported from these hosts as Ph. subflavescens or D. communis in fact represent Ph. acrocephalus. A similar scenario is true for Ph. subflavescens reported by Blagoveshtchensky (1940, 1951) from $R$. regulus, because we were able to examine his slides and can thus confirm that they represent $P h$. gustafssoni sp. nov.

\section{Philopterus acrocephalus Carriker, 1949}

Philopterus acrocephalus was described based on a single female collected from Acrocephalus luscinius, an endemic species from Guam that is extinct nowadays. Therefore in future we cannot expect to find any additional specimens from the type host. However, the holotype shows almost complete morphological unity with Philopterus collected by us from Acrocephalus melanopogon. A record of Philopterus in this host species was already published by Balat (in Hudec 1983), Vas et al. (2012a), and Diakou et al. (2017) but it was not determined at the species level. With the determination of individuals collected by us we are here able to amend the original description with a more detailed morphological description (description of male being published for the first time), figures (Figs. 1-5, 8) and also a genetic delimitation of this species (Table 5). The latter is based on comparison of the DNA sequences of one mitochondrial (COI) and two nuclear (hyp and TMEDEO) genes and their concatenated sequences; it is also the first attempt to apply the techniques of molecular biology to the taxonomy of the Philopterus- 
complex. As a result of this comparison, we present net interspecific $p$-distances of $P h$. acrocephalus from three Philopterus species, Ph. gustafssoni sp. nov., Ph. citrinellae and Ph. fringillae (Table 5). These three Philopterus species are noticeably genetically distant from Ph. acrocephalus, however, of all the Philopterus-complex specimens from which we managed to gather DNA sequences they are still its nearest relatives (Najer, unpublished results). Morphologically none of them is similar to Ph. gustafssoni sp. nov., so we do not include their comparison into morphological descriptions. Hence, we are aware that the hereby presented net interspecific distances have only limited predicative value. We believe that in future we will manage to get DNA sequences of the species which should be reportedly (Mey 1988) more closely related to $P h$. gustafssoni sp. nov.

When we compare the net interspecific to net intraspecific (Table 4) $p$-distances of particular species, it is worth noting that the intraspecific variability of $P h$. acrocephalus is mainly zero and minimal in Ph. fringillae. In both cases, just two lice from the single host species and the same location were analyzed. In contrast, in Ph. gustafssoni sp. nov. and Ph. citrinellae specimens from more than one host species and from several locations were analyzed, so the intraspecific variability is accordingly higher.

Beside the material collected by us, we also morphologically examined museum slides found either during the search for type material of already described species or randomly, while investigating other Philopterus-complex groups. In this way we discovered several undetermined slides containing Philopterus from Acrocephalus schoenobaenus, Iduna aedon rufescens, Iduna rama, and undetermined species from Locustella warblers and Locustella ochotensis. Despite being in variable conditions (with some data unreadable or even absent), all these specimens were determined as $P h$. acrocephalus after comparison to both the holotype and material collected by us. Except for A. schoenobaenus, this finding is the first record of Philopterus in the remaining host species, and in the case of Locustella sp. and Locustella ochotensis also the first record of a Philopterus-complex louse in Locustellidae. A record of head lice outside the Philopterus-complex is already known in Locustellidae (Sturnidoecus tulackovae Balat, 1981 in Locustella fluviatilis (Wolf, 1810)), so this raises the question to what extent these two convergent groups are able to share one host family. The occurrence of $P h$. acrocephalus in Locustellidaealso shows the surprisingly low specificity of $P h$. acrocephalus with regard to both host family and host body size (Locustella ochotensis vs Iduna aedon; Dyrcz 2018a, 2018b).

\section{Philopterus spp. from other reed warblers}

In terms of museum material, we further examined one Philopterus female from A. schoenobaenus collected in Egypt and labeled as Philopterus necopinatus and one male and two nymphs from Iduna aedon labeled only with host species and collection date. Both adult lice (the female from A. schoenobaenus and the male from I. aedon) are morphologically different from both Ph. acrocephalus and supposed $P h$. fedorenkoae. They also differ from each other in general head morphology (shape of preantennal part, ADP etc.) but since they belong to different genders we are not able to estimate whether they should be individuals of the same species. The description of Ph. necopinatus (Złotorzycka 1964) is based on a single male from Poland that is currently lost (Jaloszynski et al. 2014). Złotorzycka \& Lucińska (1976) present the female as unknown, so the female could not be determined at the species level and there is no clear reason for its designation as Ph. necopinatus. The male from I. aedon is in relatively good condition but not dissected.This enables assessment of its head features (on which the comparison with Ph. acrocephalus and supposed Ph. fedorenkoae is based) but part of the abdominal chaetotaxy and genitalia is not visible due to dark gut content. In general, it can be said that both individuals combine the particular features of both Ph. acrocephalus and Ph. fedorenkoae in different ways (e.g., shape of ADP or female subgenital plate), so morphologically they seem to be 'something in between'these two species. There is only one other report about Ph. necopinatus by Paz Martin-Mateo (2009), who mentioned that this species was found by Paz Martin-Mateo \& Jimenez Millan (1967) in 
A. scirpaceus. In the original paper (Paz Martin-Mateo \& Jimenez Millan 1967), it is reported under the name Philopterus communis (at least Paz Martin-Mateo 2009 states that this is the record) and the host is $A$. schoenobaenus instead of $A$. scirpaceus. We tried to get more information about this specimen by contacting M. Paz Martin-Mateo, but so far without success.

It seems that $A$. schoenobaenus could be the host of two species of Philopterus - Ph. acrocephalus and Ph. necopinatus. While we can confirm Ph. acrocephalus on this host, the status of Ph. necopinatus is still questionable until either type material or new material from the type location will be found and examined.

Also the next species, described by Złotorzycka (1964) - Philopterus mirificus - was described on the basis of one single specimen from Poland, which is currently lost (Jaloszynski et al. 2014). There is another report of Philopterus from A. palustris - the type host of Ph. mirificus - from Bulgaria by Ilieva (2009). We have found the Bulgarian specimens but up to this day we were not able to examine them, so their identity remains questionable.

The last described species, Philopterus fedorenkoae, was already reported from Turkmenistan (Mey 1983), Romania (Adam \& Sandor 2004) and some specimens from the type host - A. arundinaceus from Czechia and Slovakia were found also in Balat's collection in MMBC. Based on examined material from Balat's collection, we can confirm that $P h$. fedorenkoae is different from $P h$. acrocephalus, so it may represent a valid species. However, all our attempts to find the type material of Ph. fedorenkoae failed, so we cannot consider this conclusion as absolutely sure.

Apart from the four described species of Philopterus from Acrocephalus hosts, there are some other reports without proper species description from the following hosts: Uchida (1948) reported Ph. subflavescens from Acrocephalus orientalis from Japan. Since this name is invalid, we assume that these lice may represent genus Philopterus. We looked for these specimens in NHML, where most of the Uchida's collection is stored, but we found neither them nor any other Philopterus from Acrocephalidae, so we could not confirm this determination. Furthermore, some Philopterus were reported from A. arundinaceus from eastern Asia (McClure et al. 1973) and Acrocephalus agricola (Jerdon, 1845) from Romania (Adam et al. 2009). Finally, there is a note about Philopterus "eichleri" (syn.: Docophorulus "eichleri") (Mey 1977) from Acrocephalus scirpaceus reported from Germany. This 'species' was not described; Mey (1977) mentioned that he would describe it in future, however, this description was never realized. In all these cases, we tried to find these specimens in the institutions where they should be stored. However, all our effort was unsuccessful, often with people not replying to our inquiries, so we are not able to evaluate its quality and identification.

Apart from the taxonomic issues, we consider as interesting the $100 \%(n=28)$ prevalence of Ph. acrocephalus in A. melanopogon at Gbelce. This is in striking contrast to the fact that T. Najer and O. Sychra through the years examined hundreds of birds of five other Acrocephalus species (A. scirpaceus, A. schoenobaenus, A arundinaceus, A. palustris and a few individuals of A. paludicola (Vieillot, 1817)) in both Czechia and Slovakia and never recorded any Philopterus. This might relate to the fact that A. melanopogon is the only Acrocephalus species wintering in the Mediterranean region; all others are sub-Saharan migrants (Stastny \& Hudec 2011). Sychra et al. (2011) published consistent conclusions proving that the prevalence of lice was higher in non-migratory birds. Nonetheless, in their study the difference was not so striking as here.

The research at Gbelce took place in three years $(2008,2009,2016)$ and always in the second half of April. At Nea Agathoupoli, where the prevalence was much lower $(20 \%, n=10)$, it took place in July (2013). This may imply that in the pre-breeding period the prevalence of lice is higher than postbreeding, which is in contrast to previous Czech studies dedicated to this topic (Sychra et al. 2008, 
2011). However, it confirms the assumption of Price et al. (2003), which is also discussed by Sychra et al. (2011). According to this statement, birds in spring should have a higher prevalence and abundance of lice because of both easier horizontal transfer and more time spent feeding (at the cost of preening, compensation for the loss of energy during migration). After breeding, the lice are already vertically transferred to young birds, so the prevalence of lice is lower. Furthermore, the adults are in relatively good condition, preparing themselves for autumn migration. The higher infestation by lice in spring may be also affected by higher air humidity in this time (Clayton et al. 2016).

Sychra et al. (2011) showed a noticeable difference between pre- and post-breeding prevalence also in two Philopterus species, Ph. modularis (Denny, 1842) and Ph. turdi (Denny, 1842) collected from the Eurasian blackbird, Turdus merula Linnaeus, 1758. In Ph. turdi collected from another host, Turdus philomelos Brehm, 1831, and two other Philopterus species, Ph. rubeculae (Denny, 1842) and Ph. citrinellae, the difference is very slight. Turdus merula and Pyrrhula pyrrhula (Linnaeus, 1758) (from which they collected Ph. citrinellae) do not migrate. On the other hand, Turdus philomelos and Prunella modularis (Linnaeus, 1758) (host of Ph. modularis) winter in the Mediterranean region. This shows that the differences between pre- and post-breeding period are mixed with several migration strategies, so there is no apparent coherence with them.

Such large differences between pre- and post-breeding infestation rates do not occur in other lice genera (e.g., Menacanthus), which represent the vast majority of lice studied by Sychra et al. (2011). This leads to their recorded prevalence being practically the same in both periods. Apart from this study, it is not known whether any other head lice show such differences between pre- and post-breeding prevalence. From this point of view it would be interesting to compare, e.g., populations of Sturnidoecus sturni (Schrank, 1776) in both migrating and non-migrating populations of starling, Sturnus vulgaris Linnaeus, 1758.

\section{Philopterus from Regulidae}

Compared to Philopterus from Acrocephalidae, Ph. reguli was up to date the only species known so far in the family Regulidae. It was originally described based on a single female from Regulus regulus (Denny 1842). The records of males were published more than a century later, however, just as inaccurately described as Ph. acrocephalus (Złotorzycka 1964; Złotorzycka \& Lucińska 1976). When we examined all the abovementioned material, it turned out that the female described as $P h$. reguli and the material described in the two later studies are two different species. Whereas the material described by Złotorzycka (1964) and Złotorzycka \& Lucińska (1976) represents the same species as other Philopterus material known from Regulidae (see above), the holotype of Ph. reguli differs from it in, e.g., noticeably wider preantennal head. Therefore, we combine results of examination of all to us known Philopterus specimens from Regulidae and describe it as a new species, Ph. gustafssoni sp. nov., including its genetic delimitation (Table 5).

Beside material from the type host, Regulus regulus, we also provide a record of $P h$. gustafssoni sp. nov. in a second host species, Regulus ignicapillus. Since we genetically examined lice from two host species and two geographically distant areas (Czechia and the Azores), the ascertained intraspecific genetic variability of $P h$. gustafssoni sp. nov. is notably higher than that of $P h$. acrocephalus and Ph. fringillae (Table 4). Three different subspecies of Regulus regulus occur on the Azores (R.r. azoricus, R. $r$. sanctaemariae and $R$. $r$. inermis Murphy \& Chapin, 1929) (Clements et al. 2018) with several more living throughout Eurasia, so this host-parasite association could serve as a good model for phylogeographic studies (similar to, e.g., Stefka et al. 2011), if a more robust set of samples would be collected.

In Ph. gustafssoni sp. nov., it is also worth noting that, according to observations of I. Literak (unpublished observation), the lice did not occur only on the head of the hosts but reportedly also on 
their nape, mantle and throat. A further thorough study of the ecology of the Philopterus-complex would by all means be more than welcome to confirm or reject whether such a distribution is accidental or regular.

\section{Acknowledgements}

We thank Miroslav Capek, Tamas Judak, and Lucie Oslejskova for their help during our field trips in Slovakia. Adela Stepankova helped us with morphologically processing specimens from goldcrests and Anastasia Diakou arranged the field trip in Greece and also helped with collecting lice there. We thank the staff of the National Museum of Natural History, Smithsonian Institution, Washington, D.C., USA (USNM), the Zoological Institute, Russian Academy of Sciences, St. Petersburg, Russia (ZIN), the Natural History Museum, London, United Kingdom (NHML, particularly to Paul A. Brown) and the Museum of Natural History, University of Wrocław, Wrocław, Poland (MNHW, particularly to Pawel Jaloszynski) for enabling us to examine the museum material. We are indebted to Daniel Gustafsson for his valuable advise regarding head chaetotaxy and to two anonymous reviewers for helpful comments that improved this manuscript.

\section{References}

Adam C. \& Sandor A.D. 2004. New data on the chewing louse fauna (Phthiraptera: Amblycera, Ischnocera) from Romania. Part I. Travaux du Muséum national d'Histoire naturelle "Grigore Antipa" 46: 75-82.

Adam C., Chisamera G., Daroczi S.J., Sandor A.D. \& Gogu-Bogdan M. 2009. Data on the chewing lice fauna (Phthiraptera: Amblycera, Ischnocera) from some wild and domestic birds in Romania. Travaux du Muséum national d'Histoire naturelle "Grigore Antipa" 52: 177-232.

Ash J.S. 1960. A study of the Mallophaga of birds with particular reference to their ecology. Ibis 102 (1): 93-110. https://doi.org/10.1111/j.1474-919X.1960.tb05095.x

Balat F. 1953. Mallophaga zjistena na ptacich Moravy a Slovenska. Spisy vydavane Prirodovedeckou fakultou Masarykovy university 348: 169-176.

Balat F. 1958. Beitrag zur Kenntnis der Mallophagenfauna der bulgarischen Vögel. Prace Brnenske zakladny Ceskoslovenske akademie ved 30: 397-722.

Balat F. 1977. Enumeratio insectorum Bohemoslovakiae: Mallophaga. Acta Faunistica Entomologica Musei Nationalis Pragae, suppl. 4: 45-52.

Bechet I. 1956. Contributii la cunoasterea faunei malofagelor din R. P. R. Studii şi cerccetări de biologie. Academia Republicii Populare Romine, Filiala Cluj 7 (1/4): 137-148.

Bechet I. 1961. Malofage din Republica Populară Romina. Studii şi cerccetări de biologie, Academia Republicii Populare Romine, Filiala Cluj 12(1): 91-102.

Blagoveshtchensky D.I. 1940. Mallophaga s ptits Talysha. Parazitologicheskiy Sbornik 13: 272-327.

Blagoveshtchensky D.I. 1951. Mallophaga Tadzhikistana. Parazitologicheskiy Sbornik 13: 272-327.

Burmeister H.C.C. 1838. Mallophaga. In: Handbuch der Entomologie. Vol. 2: 418-443. Berlin.

Carriker M.A. 1949. On a collection of Mallophaga from Guam, Marianas Islands. Proceedings of the United States National Museum 100 (3254): 1-24. https://doi.org/10.5479/si.00963801.100-3254.1

Cicchino A.C. \& Castro D.C. 1996. Revisión preliminar de las especies del género Brueelia Kéler, 1936 (Phthiraptera, Philopteridae) parásitas de Icterinae (Aves, Passeriformes, Fringillidae). Graellsia 52: 3-30. https://doi.org/10.3989/graellsia.1996.v52.i0.373 
Clay T. \& Hopkins G.H.E. 1950. The early literature on Mallophaga. Part I, 1758-1762. Bulletin of the British Nuseum (Natural History) Entomology 1 (3): 221-271. https://doi.org/10.5962/bhl.part.27230

Clayton D.H., Bush S.E. \& Johnson K.P. 2016. Coevolution of Life on Hosts Integrating Ecology and History. The University of Chicago Press, Chicago.

https://doi.org/10.7208/chicago/9780226302300.001.0001

Clements J.F., Schulenberg T.S., Iliff M.J., Roberson D., Fredericks T.A., Sullivan B.L. \& Wood C.L. 2018. The eBird/Clements checklist of birds of the world: v2018. Available from http://www.birds.cornell.edu/clementschecklist/download/ [accessed 24 July 2019].

Denny H. 1842. Monographia anoplurorum Britanniae or an Essay on the British Species of Parasitic Insects. Henry G. Bohn, London. https://doi.org/10.5962/bhl.title.26900

Diakou A., Couto Soares J.B.P., Alivizatos H., Panagiotopoulou M., Kazantzidis S., Literak I. \& Sychra O. 2017. Chewing lice from wild birds in northern Greece. Parasitology International 66 (5): 699-706. https://doi.org/10.1016/j.parint.2017.07.003

Dik B., Erciyas K. \& Per E. 2017. Chewing lice (Phthiraptera: Amblycera, Ischnocera) on birds in the Kizilirmak delta, Turkey. Revue de Médecine vétérinaire 168: 53-62.

Dyrcz A. 2018a. Moustached Warbler (Acrocephalus melanopogon). In: del Hoyo J., Elliott A., Sargatal J., Christie D.A. \& de Juana E. (eds) Handbook of the Birds of the World Alive. Lynx Edicions, Barcelona. Available from https://www.hbw.com/node/58792 [accessed 14 Apr. 2020].

Dyrcz A. 2018b. Thick-billed Warbler (Arundinax aedon). In: del Hoyo J., Elliott A., Sargatal J., Christie D.A. \& de Juana E. (eds) Handbook of the Birds of the World Alive. Lynx Edicions, Barcelona. Available from https://www.hbw.com/node/58826 [accessed 14 Apr. 2020].

Fedorenko I.A. 1987. Podsemeistvo Philopterinae. In: Fauna Ukrainy 22 (9/2): 1-166. Akademia Nauk Ukrainskoi SSR, Kiev.

Geoffroy E.L. 1762. Histoire abrégée des Insectes qui se trouvent aux environs de Paris. 2 vols. Durand, Paris. https://doi.org/10.5962/bhl.title.154842

Giebel C.G. 1874. Insecta epizoa. Die auf Säugetieren und Vögeln schmarotzenden Insecten nach Chr. Nitzsch's Nachlass bearbeitet. Otto Wigand, Leipzig. https://doi.org/10.5962/bhl.title.66072

Gustafsson D.R. \& Bush S.E. 2017. Morphological revision of the hyper diverse Brueelia-complex (Insecta: Phthiraptera: Ischnocera: Philopteridae) with new taxa, checklists and generic key. Zootaxa 4313 (1): 1-443. https://doi.org/10.11646/zootaxa.4313.1.1

Gustafsson D.R., Lei L., Chu X., Zou F. \& Bush S.E. 2019. New genus and two new species of chewing lice from Southeast Asian trogons (Aves: Trogoniformes), with a revised key to the Philopterus-complex. Acta Parasitologica 64 (1): 86-102. https://doi.org/10.2478/s11686-018-00011-x

Hackman W. 1994. Mallofager (Phthiraptera: Mallophaga) som parasiterar pa Finlands fagelarter. Memoranda Societatis pro Fauna et Flora Fennica 70: 35-70.

Hopkins G.H.E. \& Clay T. 1952. A Check List of the Genera \& Species of Mallophaga. British Museum of Natural History, London. https://doi.org/10.5962/bhl.title.118844

Hudec K. 1983. Ptaci-Aves. Vol. 3(I \& II). Fauna CSSR. Academia, Praha.

Ilieva M. 2009. Checklist of the chewing lice (Insecta: Phthiraptera) from wild birds in Bulgaria. Zootaxa 2138: 1-66. https://doi.org/10.11646/zootaxa.2138.1.1 
Jaloszynski P., Gustafsson D.R., Wanat A. \& Wanat M. 2014. Type specimens of Phthiraptera in the collection of Jadwiga Złotorzycka preserved in the Museum of Natural History, University of Wrocław. Genus 25 (4): 645-661.

Johnson K.P., Adams R.J. \& Clayton D.H. 2002. The phylogeny of the louse genus Brueelia does not reflect host phylogeny. Biological Journal of the Linnean Society 77 (2): 233-247.

https://doi.org/10.1046/j.1095-8312.2002.00107.x

Kearse M., Moir R., Wilson A., Stones-Havas S., Cheung M., Sturrock S., Buxton S., Cooper A., Markowitz S., Duran C., Thierer T., Ashton B., Mentjies P. \& Drummond A. 2012. Geneious Basic: an integrated and extendable desktop software platform for the organization and analysis of sequence data. Bioinformatics 28: 1647-1649. https://doi.org/10.1093/bioinformatics/bts199

Kellogg V.L. 1896. New Mallophaga II from land birds, together with an account of the Mallophagous mouth-parts. Proceedings of the California Academy of Science (Series 2) 6: 431-548.

Kellogg V.L. 1899. New Mallophaga III. Mallophaga from birds of Panama, Baja California and Alaska. Occasional Papers of the California Academy of Sciences 6: 1-52.

Kravtsova N.T. 1998. Paraziticheskie chlenistonogie osnovnykh sinantropnykh ptits g. Bishkek i ego okrestnostey. Summary of Ph.D. thesis. Kyrgyz State Agricultural University, Bishkek, Kyrgyzstan.

Kumar S., Stecher G. \& Tamura K. 2016. MEGA7: Molecular Evolutionary Genetics Analysis version 7.0 for bigger datasets. Molecular Biology and Evolution 33 (7): 1870-1874.

https://doi.org/10.1093/molbev/msw054

McClure H.E., Ratanaworabhan N., Emerson K.C., Hoogstraal H., Nadchatram N., Kwanyuen P., Atyeo W.T., Maa T.C., Wilson N. \& Wayupong L. 1973. Some Ectoparasites of the Birds of Asia. Applied Scientific Research Corporation of Thailand.

Mey E. 1977. Über den Mallophagen-Befall bei einigen Rohrsängern und Meisen. Der Falke, Monatschrift für Ornithologie und Vogelschutz 24: 402-404.

Mey E. 1983. Docophorulus fedorenkoae sp. n. (Mallophaga). Vestnik Zoologii, Kiev 2: 31-35.

Mey E. 1988. Zur Taxonomie der auf Meisen (Paridae) parasitierenden Docophorulus-Arten (Insecta, Phthiraptera, Philopteridae). Rudolstädter Naturhistorische Schriften 1: 71-77.

Mey E. 2003. Verzeichnis der Tierläuse (Phthiraptera) Deutschlands. In: Klausnitzer B. (ed.) Entomofauna Germanica 6: 72-129. Entomologische Nachrichten und Berichte, Beiheft 8. Dresden.

Mey E. 2004. Zur Taxonomie, Verbreitung und parasitophyletische Evidenz des Philopterus-Komplexes (Insecta, Phthiraptera, Ischnocera). Ornithologischer Anzeiger 43: 149-203.

Najer T., Gustafsson D.R. \& Sychra O. 2016. Two new species of Philopteroides (Phthiraptera: Ischnocera: Philopteridae) of the beckeri-species group from New Guinean painted berrypeckers (Aves: Passeriformes: Paramythiidae). Zootaxa 4139 (4): 527-541. https://doi.org/10.11646/zootaxa.4139.4.5

Negru S. 1958. Malofage noi pentru fauna R. P. R. (Mallophaga Nitzsch). Studii și cerccetări de biologie. Biologie Animala 10 (3): 225-248.

Palma R.L. \& Jensen J.-K. 2005. Lice (Insecta: Phthiraptera) and their host associations in the Faroe Islands. Steenstrupia 29: 49-73.

Paz Martin-Mateo M. \& Jimenez Millan F. 1967. Contribucion al conocimiento de las especies de Malofagos existentes en España. Graellsia 23: 143-158.

Paz Martin-Mateo M. 2009. Phthiraptera Ischnocera. In: Ramos M.A. et al. (eds) Fauna Iberica vol. 32. Museo Nacional de Ciencias Naturales, CSIC, Madrid. 
Peters H.S. 1936. A list of external parasites from birds of the eastern part of the United States. BirdBanding 7 (1): 9-27. https://doi.org/10.2307/4509367

Piaget E. 1880. Les Pediculines: Essai monographique. Brill E.J., Leiden.

Price R.D., Hellenthal R.A. \& Palma R.L. 2003. World checklist of chewing lice with host associations and keys to families and genera. In: Price R.D., Hellenthal R.A., Palma R.L., Johnson K.P. \& Clayton D.H. (eds) The Chewing Lice: World Checklist and Biological Overview: 1-448. Illinois Natural History Survey Special Publication 24.

Seguy E. 1944. Insectes Ectoparasites (Mallophages, Anoploures, Siphonapteres). Faune de France. Vol. 43. Paul Lechevalier et Fils, Paris.

Stastny K. \& Hudec K. (eds) 2011. Ptaci - Aves 3/I. Academia, Praha.

Stefka J., Hoeck P.A.E., Keller L.F. \& Smith V.S. 2011. A hitchhikers guide to the Galapagos cophylogeography of Galapagos mockingbirds and their parasites. BMC Evolutionary Biology 11: 284. https://doi.org/10.1186/1471-2148-11-284

Sychra O., Literak I., Podzemny P. \& Benedikt V. 2008. Insect ectoparasites from wild passerine birds in the Czech Republic. Parasite 15 (4): 599-604. https://doi.org/10.1051/parasite/2008154599

Sychra O., Literak I., Nguyen M.H. \& Podzemny P. 2009. Chewing lice from wild passerines (Aves: Passeriformes) from Vietnam, with description of a new species of the genus Brueelia (Phthiraptera, Ischnocera, Philopteridae).Acta Parasitologica 54: 154-157.https://doi.org/10.2478/s11686-009-0022-6

Sychra O., Literak I., Podzemny P., Harmat P. \& Hrabak R. 2011. Insect ectoparasites on wild birds in the Czech Republic during the pre-breeding period. Parasite 18 (1): 13-19. https://doi.org/10.1051/parasite/2011181013

Sychra O., Najer T., Kounek F., Nguyen H.M. \& Tolstenkov O.O. 2014a. Myrsidea claytoni (Phthiraptera: Menoponidae) from Cymbirhynchus macrorhynchos (Passeriformes: Eurylaimidae): A case of natural host switching. Journal of Parasitology 100 (3): 280-283. https://doi.org/10.1645/13-385.1

Sychra O., Kounek F., Papousek I., Capek M., Cardenas-Callirgos J.M., Franco S. \& Literak I. 2014b. Chewing lice (Phthiraptera: Amblycera et Ischnocera) from wrens (Passeriformes: Troglodytidae), with description of a new species of Myrsidea. Acta Entomologica Musei Nationalis Pragae 54 (1): 1-27.

Svensson L., Mullarney K., Zetterström D. 2009. Collins Bird Guide, $2^{\text {nd }}$ edition. HarperCollins, London.

Sweet A.D., Allen J.M. \& Johnson K.P. 2014. Novel primers from informative nuclear loci for louse molecular phylogenetics (Insecta: Phthiraptera). Journal of Medical Entomology 51 (6): 1122-1126. https://doi.org/10.1603/ME13218

Trnka A. \& Capek M. 2002. Sasiniarik tenkozoby / trsteniarik tamariskovy. In: Danko S., Darolova A. \& Kristin A. (eds) Birds Distribution in Slovakia 496-497. Veda, Bratislava.

Uchida S. 1917. Mallophaga from birds of Formosa. Journal of the College of Agriculture, Tokyo 3: 171-188.

Uchida S. 1948. Studies on the biting-lice (Mallophaga) of Japan and adjacent territories (Suborder Ischnocera Pt. I). Japanese Medical Journal 1 (4): 303-326. https://doi.org/10.7883/yoken1948.1.303

Vas Z., Privigyei C., Prohaszka V.J., Csörgö T. \& Rozsa L. 2012a. New species and host association records for the Hungarian avian louse fauna (Insecta: Phthiraptera). Ornis Hungarica 20 (1): 44-49. https://doi.org/10.2478/orhu-2013-0004

Vas Z., Rekasi J. \& Rozsa L. 2012b. A checklist of lice of Hungary (Insecta: Phthiraptera). Annales Historico-naturales Musei Nationalis Hungarici 104: 5-109. 
Złotorzycka J. 1964. Mallophaga parasitizing Passeriformes and Pici. III. Philopterinae. Acta Parasitologica Polonica 12: 401-430.

Złotorzycka J. \& Lucińska A. 1976. Systematische Studien an europäischen Arten der Gattungen Philopterus und Docophorulus (Mallophaga, Philopteridae). II. Teil. Die Gattung Docophorulus Eichler. Polskie Pismo Entomologiczne 46: 261-318.

Manuscript received: 6 August 2019

Manuscript accepted: 21 November 2019

Published on: 22 April 2020

Topic editor: Gavin Broad

Desk editor: Natacha Beau

Printed versions of all papers are also deposited in the libraries of the institutes that are members of the EJT consortium: Muséum national d'histoire naturelle, Paris, France; Meise Botanic Garden, Belgium; Royal Museum for Central Africa, Tervuren, Belgium; Royal Belgian Institute of Natural Sciences, Brussels, Belgium; Natural History Museum of Denmark, Copenhagen, Denmark; Naturalis Biodiversity Center, Leiden, the Netherlands; Museo Nacional de Ciencias Naturales-CSIC, Madrid, Spain; Real Jardín Botánico de Madrid CSIC, Spain; Zoological Research Museum Alexander Koenig, Bonn, Germany; National Museum, Prague, Czech Republic. 